\title{
Lignocellulosic Biomass Mild Alkaline Fractionation and Resulting Extract Purification Processes: Conditions, Yields, and Purities
}

\author{
Vincent Oriez *(D), Jérôme Peydecastaing and Pierre-Yves Pontalier*(D) \\ Laboratoire de Chimie Agro-industrielle (LCA), Université de Toulouse, INRA, INPT, 4 allée Emile Monso, \\ 31030 Toulouse, France; vincent.oriez@ensiacet.fr \\ * Correspondence: vincentoriez@yahoo.fr (V.O.); pierreyves.pontalier@ensiacet.fr (P.-Y.P.)
}

Received: 11 December 2019; Accepted: 29 January 2020; Published: 14 February 2020

\begin{abstract}
Fractionation of lignocellulose is a fundamental step in the valorization of cellulose, hemicelluloses, and lignin to produce various sustainable fuels, materials and chemicals. Strong alkaline fractionation is one of the most applied processes since the paper industry has been using it for more than a century, and the mineral acid fractionation process is currently the most applied for the production of cellulosic ethanol. However, in the last decade, mild alkaline fractionation has been becoming increasingly widespread in the frame of cellulosic ethanol biorefineries. It leads to the solubilization of hemicelluloses and lignin at various extent depending on the conditions of the extraction, whereas the cellulose remains insoluble. Some studies showed that the cellulose saccharification and fermentation into ethanol gave higher yields than the mineral acid fractionation process. Besides, contrary to the acid fractionation process, the mild alkaline fractionation process does not hydrolyze the sugar polymers, which can be of interest for different applications. Lignocellulosic mild alkaline extracts contain hemicelluloses, lignin oligomers, phenolic monomers, acetic acid, and inorganic salts. In order to optimize the economic efficiency of the biorefineries using a mild alkaline fractionation process, the purification of the alkaline extract to valorize its different components is of major importance. This review details the conditions used for the mild alkaline fractionation process and the purification techniques that have been carried out on the obtained hydrolysates, with a focus on the yields and purities of the different compounds.
\end{abstract}

Keywords: Lignocellulose; mild alkaline fractionation; hemicelluloses and lignin; extract purification; yield and purity

\section{Introduction}

Second generation biorefineries essentially aim at valorizing sugar polymers-cellulose and hemicelluloses-from lignocellulosic biomass. The first process step of such biorefineries is to fractionate the biomass into cellulose, hemicelluloses, and lignin. However, biomasses from plants are naturally recalcitrant, and therefore in order to increase the accessibility of cellulose and hemicelluloses, the hemicelluloses-lignin complex cross-links must be broken [1,2]. The major fractionation processes studied are biological, physical and chemical sometimes with some combinations [3]. Mineral acid fractionation is currently the method of choice in several model processes for ethanol production from lignocellulosic biomasses [4,5].

However, the papermaking industry was the first historical lignocellulosic biorefinery, where severe alkaline conditions were applied to fractionate lignocellulosic biomass. The first patents where strong alkaline solutions were used to produce cellulose from wood were recorded in the second half of the $19^{\text {th }}$ century $[6,7]$. Commercial pulping processes include the soda, the sulfite, and the sulfate 
(also known as Kraft) processes. These processes induce the dissociation of cellulose fibers from lignin and hemicelluloses by the cooking chemicals [8,9]. Kraft and soda processes rely on alkaline chemicals, the former being mainly used for wood hydrolysis, while the latter is commonly applied to non-wood biomass, such as bagasse, straw, grass or bamboo [9]. In both processes, lignin, low molecular weight hemicelluloses and other extractives from the wood are dissolved in what is called the black liquor [10]. The third process in the papermaking industry is the sulfite process, developed by Tilghman [11]. The wood chips are cooked in a mixture of sulfurous acid and bisulfide ions which dissolve lignin and hemicelluloses [12]. Sulfite pulps account for less than $10 \%$ of the total chemical pulp production [13].

For decades, the black liquor was burnt to produce steam and electricity. The characterization, fractionation, and recovery of the compounds from black liquor in order to valorize them into materials and chemicals appeared only in the 1980s [14,15]. With the expansion of lignocellulosic biorefineries to produce other materials than paper - energy (liquid fuels like ethanol) and chemical intermediates - and the constraint of limiting the cost of the fractionation step, mild alkaline fractionation gained importance [16,17]. It also challenges the acid fractionation process, currently used in most second-generation ethanol biorefineries, since improved overall ethanol yields were obtained with mild alkaline fractionation followed by enzymatic saccharification [18] and it can reduce the need for expensive equipment to deal with corrosion and severe reaction conditions [17].

Besides, lignin and hemicelluloses are extracted under their oligomeric form in alkaline media which represents alternative opportunities of valorization. Hemicelluloses under their polymeric form can form hydrogels thanks to their numerous properties such as adsorption capacity, mechanical strength, hydrophilicity, biodegradability, biocompatibility, transparency, low cost, and non-toxicity which find applications in various fields such as water depollution, food additives, food packaging, cosmetics and pharmaceuticals [19-21]. The use of hemicelluloses under their polymeric form is not commercially as advanced as their use under their monomeric form.

Unlike hemicelluloses, all current commercial uses of lignin, except the burning and production of synthetic vanillin, take advantage of lignin's polymer and polyelectrolyte properties [22]. Currently, the main applications include dispersants, emulsifiers, binders and sequestrant [22]. Lignin can be used for new applications having a higher value and larger markets such as bioplastics, composites, nanoparticles, adsorbents, resins (especially for formaldehyde-free resins) and carbon fibers [22,23]. To facilitate the modification of the lignin, e.g., polymerization to form resins; sulfur-free lignin obtained through mild alkaline extraction among other processes (e.g., soda pulping or Organosolv process) are more interesting than the thio-lignin obtained through the traditional pulp and paper processes (i.e., sulfite and sulfate processes) [24].

Under alkaline conditions, phenolic monomers (mainly ferulic and $p$-coumaric acid) forming bridges between lignin units and carbohydrates are solubilized in the extract. These molecules can be used as food additives, in cosmetic and pharmaceutical products due to their antioxidant activity, cholesterol-lowering activity, prevention against thrombosis and atherosclerosis, antimicrobial and anti-inflammatory activity, and anticancer effect [25-27]. Ferulic acid can also be used to produce vanillin, another important synthon, by microbial transformation [28].

In this review, the mild alkaline fractionation of lignocellulosic biomass is explained in the first part. The purification of the resulting lignocellulosic alkaline hydrolysate is exposed in the second part of this review. A focus was put on the conditions used for the different fractionation and purification processes and on the associated yields and purities of the extracted and purified molecules. The cost and environmental impact of the different processes are not detailed in this review, only general trends are provided. 


\section{Mild Alkaline Fractionation}

\subsection{Effect and Mechanism}

The main features of mild alkaline extraction, similar to Kraft or soda pulp and paper processes, are that it solubilizes both lignin and hemicelluloses without degrading cellulose, and it increases the porosity and surface area of cellulose, thereby enhancing potential enzymatic hydrolysis of cellulose $[2,16,17]$. The solid residue (mainly cellulose) can be used in its polymeric form in an application such as paper and cellulose derivatives (e.g., cellulose acetate), or in its monomeric form (glucose), after acid or enzymatic hydrolysis of the $\beta 1-4$ glycosidic bonds, in applications such as biofuels (ethanol) and chemical intermediates [4,17]. Less than 3\% degradation of glucan (accounting for cellulose) was reported on mild alkaline extraction of sugarcane bagasse (SCB) $[29,30]$. Hemicelluloses are usually dissolved to a lower extent than lignin $[4,16]$. Conditions are milder than with acid extraction which can eliminate the need for expensive materials and special designs to cope with the corrosion of the vessels [17]. However, reaction times are usually longer and unlike acid fractionation, a limitation occurs because some of the alkaline chemicals are converted to irrecoverable salts or incorporated as salts into the biomass by the fractionation reactions [31]. Mild alkaline fractionation and the alkaline pulping processes (i.e., Kraft and soda processes) share the same fundamental principles; therefore, the mature techniques and equipment used in the pulping process, for instance, to recover the reaction chemicals as well as energy, are applicable to the mild alkaline fractionation process [32]. The activation energy (50-54 kJ/mol) used for delignification of herbaceous species (e.g., bagasse and corn stover) by mild alkaline fractionation is lower than that required for delignification of wood by the Kraft process [33], making mild alkaline extraction particularly suitable for herbaceous biomass.

The treatment of lignocellulosic biomasses by alkaline solutions induces several mechanisms. Cellulose swells due to the disruption of intermolecular hydrogen bonds that bind cellulose molecules together [34]. In parallel, some alkali-labile linkages between lignin monomers or lignin and polysaccharides are broken (Figure 1). The ester-linked substituents of the hemicelluloses (acetate groups, uronic molecules) are also broken, as well as ester-linked phenolic monomers such as ferulic acid (FA), $p$-coumaric acid ( $p$-CA) and sinapic acid $[16,35,36]$. This improves the digestibility of the undissolved hemicelluloses recovered in the solid residue and the dissolved hemicelluloses are quite similar to the native polysaccharides, except for the removed groups (acetate) or molecules (uronic acids, phenolic acids) [37,38]. The dissolved hemicelluloses contain a relatively small amount of bound lignin $(0-5 \%)$ [39]. Xylans undergo only partial hydrolysis in alkaline solution at room temperature. An increase in the severity of the treatment (e.g., base concentration or temperature) produces smaller oligomers [24,39]. 


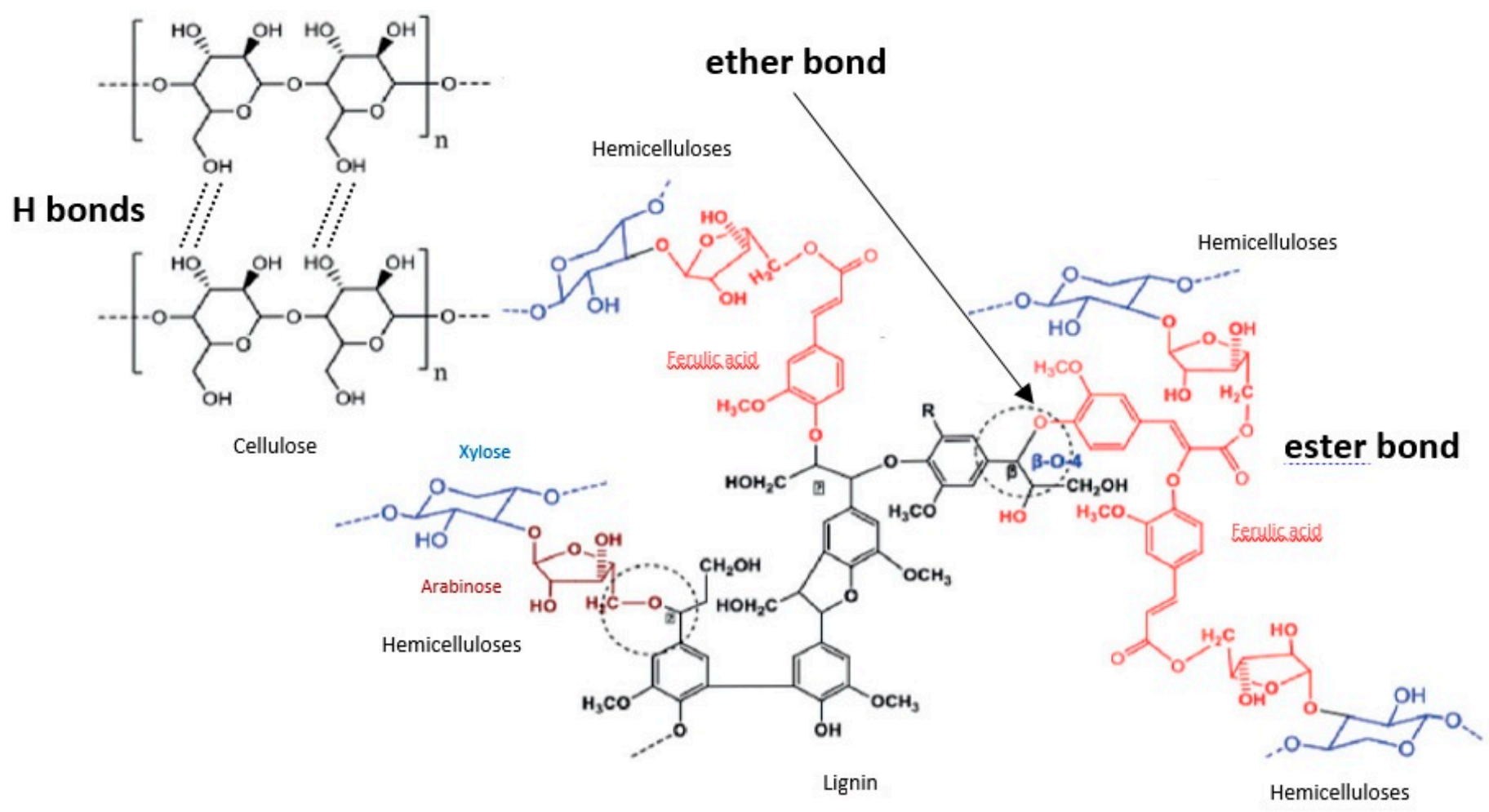

Figure 1. Alkali-labile linkages between lignocellulose components. 
Lignin is insoluble under neutral or acidic conditions, its solubilization in alkaline conditions comes from acidic moieties such as carboxylic or phenolic groups that are ionized in alkaline media, and its hydrolysis comes from the cleavage of $\beta-\mathrm{O}-4$ ether bonds in poly-phenolic units $[34,40]$. Molecules linked to lignin by their carboxyl group via ester bonds such as uronic acids, $p$-CA, FA are cleaved in mild alkaline media whereas some of the FA molecules linked by their phenolic group via ether bond requires stronger alkaline conditions to be cleaved [41-43]. Lignin extracted under mild alkaline fractionation contain a very low level of bound sugars (1-3\%) [37]. Besides, alkaline solutions are a better reaction media than acidic or neutral media, for the valorization of lignin for the synthesis of phenolic resins [44].

Lignin issued from alkaline fractionation is sulfur-free, unlike the lignin produced by Kraft and sulfite pulping processes, which is a great advantage for further chemical activation, opening up valorization pathways, for instance as fuel additives or bio-based polymers (adhesives and asphalt extenders) [17].

\subsection{Nature of the Base}

Lignocellulosic biomass can be treated with an alkali such as sodium, potassium, calcium and ammonium hydroxides at ambient temperature and pressure [45]. Among the different alkalis, sodium hydroxide has received the most attention [31] and is typically preferred because of the high extraction yields for lignin (60-80\%) and hemicelluloses $(50 \%)[17,46]$.

Calcium hydroxide, or lime, is also commonly employed for fractionation under alkaline conditions [45] because it has a lower cost, fewer safety requirements, it is less corrosive and can be recovered from the hydrolysate by reaction with $\mathrm{CO}_{2}$ so that the carbonate formed, can then be reconverted to lime [47]. Lime fractionation leads to the extraction of lignin and hemicelluloses because it cleaves $\alpha$ - and $\beta$-ether bonds in phenolic units and $\beta$-ether bonds in non-phenolic units [48] and to the removal of acetyl groups from hemicelluloses [17]. However, its fractionation effect is not as strong as with sodium hydroxide or ammonia [46]. For instance, under similar conditions, the use of sodium hydroxide led to lignin and hemicelluloses removal yields of 70 and $22 \%$, respectively, whereas the use of calcium hydroxide led to lignin and hemicelluloses removal yields of 28 and $8 \%$, respectively [29].

Aqueous ammonia treatment differs from other alkali fractionation processes as it is run at elevated temperatures or high pressures or for long durations (e.g., over $170^{\circ} \mathrm{C}$ for $1 \mathrm{~h} 30$ at atmospheric pressure, or $100{ }^{\circ} \mathrm{C}$ for $5 \mathrm{~min}$ at $20 \mathrm{bar}$, or $75{ }^{\circ} \mathrm{C}$ for $48 \mathrm{~h}$ at atmospheric pressure) $[45,49]$. These conditions correspond to three types of ammonia fractionation: ammonia recycle percolation (high temperatures), ammonia fiber explosion (high pressures) and soaking in aqueous ammonia (long durations). The three processes sufficiently reduce lignin content (65 to $75 \%$ delignification) and remove some hemicelluloses (up to $92 \%$ ), while cellulose is decrystallized, leading to an improved yield of enzymatic saccharification $[45,49]$. The use of ammonia requires recycling, to reduce the cost of the fractionation process as ammonia is expensive, and special care as ammonia is toxic for the environment. 


\subsection{Conditions and Yields}

Contrary to the pulp and paper industry, where extraction conditions are drastic regarding base concentration, temperature or pressure [10,50], fractionation conditions studied in the frame of the lignocellulosic ethanol biorefinery are milder [18,51].

Mild alkali treatment was shown to be more effective on agricultural residues than on wood materials [3]. Mild reaction conditions prevent condensation of lignin leading to its high solubility and greater removal [45]. In the frame of second-generation ethanol biorefinery, and similarly to acid fractionation processes [5], comparing the efficiency of various mild alkaline fractionation processes based on the dissolution of lignin and hemicelluloses is more relevant than comparing yields of saccharification or fermentation at the following process steps, since saccharification and fermentation conditions differ from one study to another. One might target high rates of solubilization, particularly for lignin, as they are coupled with high yields of saccharification at the next step $[29,32,52]$ and it potentially allows the purification and valorization of larger quantities of lignin and hemicelluloses. Alkali fractionation conditions with sodium hydroxide at $0.5-10.0 \%(\mathrm{w} / \mathrm{v})$ and with a solid:liquid ratio (S:L ratio) of $10-30 \%(\mathrm{w} / \mathrm{v})$ at $60-180{ }^{\circ} \mathrm{C}$ during $5-60 \mathrm{~min}$ give generally about $50-80 \%$ dissolution rate for lignin and hemicelluloses (Table 1). In Table 1, SCB was taken as the model biomass, as it is one of the most studied lignocellulosic biomasses and it contains mainly 3 sugars-glucose, xylose, arabinose-facilitating the comparison between the different processes regarding conditions and obtained yields of solubilization for lignin and hemicelluloses. Other biomasses are presented as a comparison with the reference. Sodium hydroxide was taken as the reference for the base, as it was the most studied and led to higher yields. 
Table 1. Yields of solubilization for lignin and hemicelluloses after optimized mild alkaline fractionation on various lignocellulosic agricultural residues. SCB, sugarcane bagasse; $\mathrm{S}: \mathrm{L}$, solid:liquid.

\begin{tabular}{|c|c|c|c|c|}
\hline Biomass & Variable & Optimized Conditions & Solubilization Yields & Reference \\
\hline SCB (dewaxed) & $\begin{array}{c}1-3 \% \mathrm{NaOH}(\mathrm{w} / \mathrm{v}) \\
\text { No variation of S:L ratio } \\
\text { No variation of temperature } \\
\text { No variation of duration }\end{array}$ & $\begin{array}{c}3 \% \mathrm{NaOH}(\mathrm{w} / \mathrm{v}) \\
\mathrm{S}: \mathrm{L} \text { ratio of } 1: 25 \\
50{ }^{\circ} \mathrm{C} \\
3 \mathrm{~h}\end{array}$ & $\begin{array}{c}54 \% \text { lignin } \\
75 \% \text { hemicelluloses }\end{array}$ & [53] \\
\hline SCB (dewaxed) & $\begin{array}{c}\text { No variation of alkaline concentration } \\
\text { No variation of } S: L \text { ratio } \\
\text { No variation of temperature } \\
\text { No variation of duration }\end{array}$ & $\begin{array}{c}2 \% \mathrm{NaOH}(\mathrm{w} / \mathrm{v}) \\
\mathrm{S}: \mathrm{L} \text { ratio of } 1: 30 \\
55^{\circ} \mathrm{C} \\
2 \mathrm{~h}\end{array}$ & $\begin{array}{c}55 \% \text { lignin } \\
48 \% \text { hemicelluloses }\end{array}$ & [54] \\
\hline $\mathrm{SCB}$ & $\begin{array}{c}2-6 \% \mathrm{NaOH}(\mathrm{w} / \mathrm{v}) \\
\text { No variation of } \mathrm{S}: \mathrm{L} \text { ratio } \\
150-1900^{\circ} \mathrm{C} \\
40-80 \mathrm{~min}\end{array}$ & $\begin{array}{c}4 \% \mathrm{NaOH} \\
\text { S:L ratio 5:1 } \\
170{ }^{\circ} \mathrm{C} \\
1 \mathrm{~h}\end{array}$ & $43 \%$ hemicelluloses & [55] \\
\hline SCB & $\begin{array}{c}\text { No variation of alkaline concentration } \\
\text { No variation of S:L ratio } \\
\text { No variation of temperature } \\
\text { No variation of duration }\end{array}$ & $\begin{array}{c}1.5 \% \mathrm{NaOH}(\mathrm{w} / \mathrm{v}) \\
\text { S:L ratio of } 1: 20(\mathrm{w} / \mathrm{v}) \\
60{ }^{\circ} \mathrm{C} \\
6 \mathrm{~h}\end{array}$ & $\begin{array}{l}46 \% \text { lignin } \\
22 \% \text { xylan } \\
50 \% \text { arabinan }\end{array}$ & [30] \\
\hline SCB & $\begin{array}{c}\text { No variation of alkaline concentration } \\
\text { No variation of S:L ratio } \\
\text { No variation of temperature } \\
\text { No variation of duration }\end{array}$ & $\begin{array}{c}2 \% \mathrm{NaOH}(\mathrm{w} / \mathrm{v}) \\
\mathrm{S}: \mathrm{L} \text { ratio } 1: 10(\mathrm{w} / \mathrm{v}) \\
80{ }^{\circ} \mathrm{C} \\
2 \mathrm{~h}\end{array}$ & $\begin{array}{l}70 \% \text { lignin } \\
22 \% \text { xylan } \\
22 \% \text { arabinan }\end{array}$ & [29] \\
\hline
\end{tabular}


Table 1. Cont.

\begin{tabular}{|c|c|c|c|c|}
\hline Biomass & Variable & Optimized Conditions & Solubilization Yields & Reference \\
\hline $\mathrm{SCB}$ & $\begin{array}{c}\text { No variation of alkaline concentration } \\
\text { No variation of S:L ratio } \\
\text { No variation of temperature } \\
\text { No variation of duration }\end{array}$ & $\begin{array}{c}2 \% \mathrm{Ca}(\mathrm{OH})_{2}(\mathrm{w} / \mathrm{v}) \\
\mathrm{S}: \mathrm{L} \text { ratio } 1: 10(\mathrm{w} / \mathrm{v}) \\
80{ }^{\circ} \mathrm{C} \\
2 \mathrm{~h}\end{array}$ & $\begin{array}{l}28 \% \text { lignin } \\
9 \% \text { xylan } \\
6 \% \text { arabinan }\end{array}$ & [29] \\
\hline SCB & $\begin{array}{c}\text { No variation of alkaline concentration } \\
\text { No variation of S:L ratio } \\
\text { No variation of temperature } \\
\text { No variation of duration }\end{array}$ & $\begin{array}{c}1 \% \mathrm{Ca}(\mathrm{OH})_{2}(\mathrm{w} / \mathrm{v}) \\
\text { S: } \mathrm{L} \text { ratio of } 1: 10 \\
120^{\circ} \mathrm{C} \\
1 \mathrm{~h}\end{array}$ & $\begin{array}{c}14 \% \text { lignin } \\
0 \% \text { hemicelluloses }\end{array}$ & [47] \\
\hline SCB & $\begin{array}{c}\text { No variation of alkaline concentration } \\
\text { No variation of S:L ratio } \\
\text { No variation of temperature } \\
7-60 \mathrm{~min}\end{array}$ & $\begin{array}{c}1 \% \mathrm{Ca}(\mathrm{OH})_{2}(\mathrm{w} / \mathrm{v}) \\
\mathrm{S}: \mathrm{L} \text { ratio of } 1: 100 \\
120{ }^{\circ} \mathrm{C} \\
1 \mathrm{~h}\end{array}$ & $\begin{array}{c}30 \% \text { lignin } \\
5 \% \text { hemicelluloses }\end{array}$ & {$[48]$} \\
\hline SCB & $\begin{array}{c}0.03-0.3 \% \mathrm{NH}_{3}(\mathrm{w} / \mathrm{w}) \\
\text { No variation of } \mathrm{S}: \mathrm{L} \text { ratio } \\
\text { No variation of temperature } \\
0-40 \text { day }\end{array}$ & $\begin{array}{c}0.3 \% \mathrm{NH}_{3}(\mathrm{w} / \mathrm{w}) \\
\text { S:L ratio of } 1: 8(\mathrm{w} / \mathrm{v}) \\
30{ }^{\circ} \mathrm{C} \\
40 \text { day }\end{array}$ & $\begin{array}{c}\text { 46\% lignin } \\
\text { 27\% hemicelluloses }\end{array}$ & [56] \\
\hline SCB & $\begin{array}{c}20-28 \% \mathrm{NH}_{3}(\mathrm{v} / \mathrm{v}) \\
\text { No variation of } \mathrm{S}: \mathrm{L} \text { ratio } \\
50-70{ }^{\circ} \mathrm{C} \\
8-24 \mathrm{~h}\end{array}$ & $\begin{array}{c}20 \% \mathrm{NH}_{3}(\mathrm{v} / \mathrm{v}) \\
\text { S:L ratio of } 1: 10(\mathrm{w} / \mathrm{v}) \\
70{ }^{\circ} \mathrm{C} \\
24 \mathrm{~h}\end{array}$ & $\begin{array}{c}42 \% \text { lignin } \\
69 \% \text { hemicelluloses }\end{array}$ & [57] \\
\hline Wheat straw & $\begin{array}{c}3 \% \mathrm{NaOH}(\mathrm{w} / \mathrm{v}) \\
\mathrm{S}: \mathrm{L} \text { ratio of } 1: 26.6(\mathrm{w} / \mathrm{v}) \\
45^{\circ} \mathrm{C} \\
2-15 \mathrm{~h}\end{array}$ & $\begin{array}{c}3 \% \mathrm{NaOH}(\mathrm{w} / \mathrm{v}) \\
\mathrm{S}: \mathrm{L} \text { ratio of } 1: 26.6(\mathrm{w} / \mathrm{v}) \\
45^{\circ} \mathrm{C} \\
15 \mathrm{~h}\end{array}$ & $70 \%$ lignin & [37] \\
\hline
\end{tabular}


Table 1. Cont

\begin{tabular}{|c|c|c|c|c|}
\hline Biomass & Variable & Optimized Conditions & Solubilization Yields & Reference \\
\hline Wheat straw & $\begin{array}{l}0.5-10 \% \mathrm{NaOH}(\mathrm{w} / \mathrm{v}) \\
\text { No variation of S:L ratio } \\
0-80{ }^{\circ} \mathrm{C} \\
0-144 \mathrm{~h}\end{array}$ & $\begin{array}{l}1.5 \% \mathrm{NaOH}(\mathrm{w} / \mathrm{v}) \\
\mathrm{S}: \mathrm{L} \text { ratio } 1: 40(\mathrm{w} / \mathrm{v}) \\
20{ }^{\circ} \mathrm{C} \\
144 \mathrm{~h}\end{array}$ & $\begin{array}{c}\text { 59\% lignin } \\
83 \% \text { hemicelluloses }\end{array}$ & {$[34]$} \\
\hline Wheat straw & $\begin{array}{l}0.5-10 \% \mathrm{NaOH}(\mathrm{w} / \mathrm{v}) \\
\text { No variation of S:L ratio } \\
0-80{ }^{\circ} \mathrm{C} \\
0-144 \mathrm{~h}\end{array}$ & $\begin{array}{c}1.5 \% \mathrm{NaOH}(\mathrm{w} / \mathrm{v}) \\
\text { S:L ratio } 1: 40(\mathrm{w} / \mathrm{v}) \\
80{ }^{\circ} \mathrm{C} \\
6 \mathrm{~h}\end{array}$ & $\begin{array}{c}62 \% \text { lignin } \\
75 \% \text { hemicelluloses }\end{array}$ & [34] \\
\hline Wheat straw & $\begin{array}{c}0.5-10 \% \mathrm{NaOH}(\mathrm{w} / \mathrm{v}) \\
\text { No variation of } \mathrm{S}: \mathrm{L} \text { ratio } \\
0-80{ }^{\circ} \mathrm{C} \\
0-144 \mathrm{~h}\end{array}$ & $\begin{array}{c}10 \% \mathrm{NaOH}(\mathrm{w} / \mathrm{v}) \\
\mathrm{S}: \mathrm{L} \text { ratio } 1: 40(\mathrm{w} / \mathrm{v}) \\
20{ }^{\circ} \mathrm{C} \\
6 \mathrm{~h}\end{array}$ & $\begin{array}{c}47 \% \text { lignin } \\
81 \% \text { hemicelluloses }\end{array}$ & [34] \\
\hline Maize stems & $\begin{array}{c}\text { No variation of alkaline concentration } \\
\text { No variation of S:L ratio } \\
\text { No variation of temperature } \\
\text { No variation of duration }\end{array}$ & $\begin{array}{l}4 \% \mathrm{NaOH}(\mathrm{w} / \mathrm{v}) \\
\mathrm{S}: \mathrm{L} \text { ratio of } 1: 100 \\
30{ }^{\circ} \mathrm{C} \\
18 \mathrm{~h}\end{array}$ & $\begin{array}{c}\text { 78\% lignin } \\
72 \% \text { hemicelluloses }\end{array}$ & [58] \\
\hline Rye straw & $\begin{array}{c}\text { No variation of alkaline concentration } \\
\text { No variation of } S: L \text { ratio } \\
\text { No variation of temperature } \\
\text { No variation of duration }\end{array}$ & $\begin{array}{c}4 \% \mathrm{NaOH}(\mathrm{w} / \mathrm{v}) \\
\text { S:L ratio of } 1: 100 \\
30{ }^{\circ} \mathrm{C} \\
18 \mathrm{~h}\end{array}$ & $\begin{array}{c}\text { 79\% lignin } \\
73 \% \text { hemicelluloses }\end{array}$ & [58] \\
\hline Rice straw & $\begin{array}{c}\text { No variation of alkaline concentration } \\
\text { No variation of S:L ratio } \\
\text { No variation of temperature } \\
\text { No variation of duration }\end{array}$ & $\begin{array}{l}4 \% \mathrm{NaOH}(\mathrm{w} / \mathrm{v}) \\
\mathrm{S}: \mathrm{L} \text { ratio of } 1: 100 \\
30^{\circ} \mathrm{C} \\
18 \mathrm{~h}\end{array}$ & $\begin{array}{c}82 \% \text { lignin } \\
85 \% \text { hemicelluloses }\end{array}$ & [58] \\
\hline
\end{tabular}


Table 1. Cont

\begin{tabular}{|c|c|c|c|c|}
\hline Biomass & Variable & Optimized Conditions & Solubilization Yields & Reference \\
\hline \multirow{4}{*}{ Sorghum bagasse } & $2-10 \% \mathrm{NaOH}(\mathrm{w} / \mathrm{v})$ & $4 \% \mathrm{NaOH}(\mathrm{w} / \mathrm{v})$ & \multirow{4}{*}{$\begin{array}{l}76 \% \text { lignin } \\
60 \% \text { xylan }\end{array}$} & \multirow{4}{*}{ [32] } \\
\hline & No variation of S:L ratio & $\mathrm{S}: \mathrm{L}$ ratio of $1: 20(\mathrm{w} / \mathrm{v})$ & & \\
\hline & No variation of temperature & $25^{\circ} \mathrm{C}$ & & \\
\hline & $0.5-2 \mathrm{~h}$ & $2 \mathrm{~h}$ & & \\
\hline \multirow{4}{*}{ Sorghum bagasse } & $2-10 \% \mathrm{NaOH}(\mathrm{w} / \mathrm{v})$ & $10 \% \mathrm{NaOH}(\mathrm{w} / \mathrm{v})$ & \multirow{4}{*}{$\begin{array}{l}80 \% \text { lignin } \\
81 \% \text { xylan }\end{array}$} & \multirow{4}{*}{ [32] } \\
\hline & No variation of S:L ratio & $\mathrm{S}: \mathrm{L}$ ratio of $1: 20(\mathrm{w} / \mathrm{v})$ & & \\
\hline & No variation of temperature & $25^{\circ} \mathrm{C}$ & & \\
\hline & $0.5-2 \mathrm{~h}$ & $2 \mathrm{~h}$ & & \\
\hline
\end{tabular}


Four main parameters influence the dissolution of hemicelluloses and lignin during mild alkaline fractionation: base concentration, S:L ratio, temperature and duration of the treatment. Increasing the value of one parameter increases the solubilization for lignin and hemicelluloses, or it can be compensated by decreasing the value of another parameter to maintain the yields of solubilization stable. For instance, on apple tree pruning residues, decreasing the S:L ratio from 1:18 to 1:10 (w/v) during mild alkaline extraction $\left(7.5 \% \mathrm{NaOH}(\mathrm{w} / \mathrm{w})\right.$, at $90{ }^{\circ} \mathrm{C}$ for $\left.90 \mathrm{~min}\right)$ led to an increase of $53 \%$ for the delignification [59]. Optimal conditions for delignification (up to 60\%) and dissolution of hemicelluloses (up to $80 \%$ ) on wheat bran were obtained with $1.5 \%(\mathrm{w} / \mathrm{v})$ sodium hydroxide and a S:L ratio of $1: 40(\mathrm{w} / \mathrm{v})$ at $20^{\circ} \mathrm{C}$ for $144 \mathrm{~h} \mathrm{[34].} \mathrm{Similar} \mathrm{yields} \mathrm{of} \mathrm{solubilization} \mathrm{were} \mathrm{achieved} \mathrm{by} \mathrm{increasing} \mathrm{the} \mathrm{temperature} \mathrm{to}$ $80^{\circ} \mathrm{C}$ and decreasing the duration of the treatment to $6 \mathrm{~h}$. The same phenomenon was observed on SCB with alkaline fractionation using calcium hydroxide; high temperatures $\left(85-135^{\circ} \mathrm{C}\right)$ coupled with short treatment duration (1-3 h) gave similar yields of glucose at the following saccharification step, as fractionation with lower temperatures $\left(50-65^{\circ} \mathrm{C}\right)$ and a longer treatment duration $(24 \mathrm{~h})$ [47]. During the last decade, methodical optimization of these parameters through response surface methodology to maximize the yield of monomeric sugars, after alkaline pretreatment and enzymatic hydrolysis, was developed [60-63]. Overall, independently from the studied lignocellulosic biomass, the results using statistical optimization were in the same range of values for the four different parameters to maximize the yields of solubilization, like those found by previous studies (Table 1). However, the coupling of optimization through response surface methodology with cost analysis was explored only recently. For instance, Łukajtis et al. (2018), showed that the best parameters to optimize glucose yield (alkaline concentration, time, duration, biomass particle size) following Box-Behnken design on energetic willow were $7 \% \mathrm{NaOH}(\mathrm{w} / \mathrm{v}), 65^{\circ} \mathrm{C}$ and $6 \mathrm{~h}$ and a particle size of $0.25 \mathrm{~mm}$ [63]. The biomass particle size is another parameter significantly influencing the efficiency of the pretreatment, but since reducing the size of the biomass is very costly compared to changing the value of other parameters (e.g., increasing the temperature), it is not cost-effective to grind biomass to less than $2 \mathrm{~mm}$ [63]. With low S:L ratios $(1: 40-1: 30(\mathrm{w} / \mathrm{v}))$, low temperatures $\left(20-60^{\circ} \mathrm{C}\right)$ and short treatment durations $(2-6 \mathrm{~h})$, increasing the sodium hydroxide concentration increased the dissolution rate for lignin and hemicelluloses, at first rapidly until a concentration of about $1.5 \%(\mathrm{w} / \mathrm{v})$, then a further increase in concentration led to a smaller increase in dissolution rates [34,54]. During mild alkaline treatment, the dissolution rates for lignin and hemicelluloses vs. time are different depending on the lignocellulosic feedstock. The dissolution rate for hemicelluloses was quicker than the dissolution rate for lignin on wheat bran [34], but the reverse phenomenon was observed on sweet sorghum bagasse [32].

The alkaline conditions for fractionation have an impact on the size and the functional groups of the dissolved lignin oligomers [22]. Soft alkaline extraction conditions helped in producing large oligomers $[24,39]$. These polymers could be interesting for some applications where a long chain of lignin or hemicelluloses are looked for, as non-exhaustively in coatings, surfactants, adhesives and cosmetics applications. [19,22]. Along with lignin oligomers and hemicelluloses, phenolic monomers are released during mild alkaline treatment of lignocellulosic biomass. The content and nature of the phenolic monomers vary from one biomass to another, but the major phenolic monomers released are $p$-CA and FA with about $1 \mathrm{~g}$ for each compound extracted from $100 \mathrm{~g}$ of biomass $[27,64,65]$.

The yields of solubilization for lignin and hemicelluloses from lignocellulosic biomass after mild alkaline fractionation with sodium hydroxide can be increased with the addition of different chemicals during the fractionation [45]. For instance, with a peroxide-alkaline fractionation $\left(4 \% \mathrm{H}_{2} \mathrm{O}_{2}(\mathrm{w} / \mathrm{v})\right.$, $0.25 \% \mathrm{MgSO}_{4}(\mathrm{w} / \mathrm{v}), \mathrm{pH}$ of 11.6 adjusted with $\mathrm{NaOH}, \mathrm{S}: \mathrm{L}$ ratio of $\left.1: 20(\mathrm{w} / \mathrm{v}), 40{ }^{\circ} \mathrm{C}, 10 \mathrm{~h}\right)$ on SCB, the yields of solubilization for lignin and hemicelluloses reached $88 \%$ and $95 \%$, respectively [66]. As for the other fractionation conditions reported, a change in the value of one parameter influenced the yields of solubilization for lignin and hemicelluloses. For instance, a decrease in the S:L ratio from 1:10 to 1:30 (w/v) increased the removal rates for lignin and hemicelluloses from $66 \%$ to $72 \%$ and from 79 to $85 \%$, respectively [54]. However, the high cost of hydrogen peroxide and the requirement for 
reaction vessels that can withstand oxidative conditions are important drawbacks regarding the use of hydrogen peroxide [45].

Overall, several studies showed that mild alkaline treatments combined with enzymatic saccharification led to higher yields for monomeric sugars, than acid treatments alone or followed by enzymatic saccharification, and therefore to higher yields for ethanol in the downstream fermentation step. For instance, on agave bagasse and sugarcane bagasse a dilute acid treatment $(1.2 \% \mathrm{HCl}(\mathrm{v} / \mathrm{v})$, S:L ratio of $1: 15,121^{\circ} \mathrm{C}, 4 \mathrm{~h}$ ) yielded 10 and $37 \%$ reducing sugars, respectively, whereas an alkaline treatment $\left(2 \% \mathrm{NaOH}(\mathrm{w} / \mathrm{v}), \mathrm{S}: \mathrm{L}\right.$ ratio of $\left.1: 5,121{ }^{\circ} \mathrm{C}, 4 \mathrm{~h}\right)$ followed by enzymatic saccharification yielded about $50 \%$ reducing sugars for both materials [67]. On sorghum bagasse, alkaline treatment $(2 \% \mathrm{NaOH}$ $(\mathrm{w} / \mathrm{v}), \mathrm{S}: \mathrm{L}$ ratio of $1: 20,25^{\circ} \mathrm{C}, 2 \mathrm{~h}$ ) followed by enzymatic saccharification was more efficient to produce monomeric sugars than acid fractionation $\left(0.5 \% \mathrm{H}_{2} \mathrm{SO}_{4}(\mathrm{w} / \mathrm{w})\right.$, S:L ratio of $\left.1: 20,170{ }^{\circ} \mathrm{C}, 0.5 \mathrm{~h}\right)$ with yield of $92 \%$ and $70 \%$, respectively [32]. Increasing sodium hydroxide concentration to $10 \%(\mathrm{w} / \mathrm{v})$ even led to a yield of $99 \%$. On rice hull, with an alkaline peroxide treatment $\left(7.5 \% \mathrm{H}_{2} \mathrm{O}_{2}(\mathrm{v} / \mathrm{v}), \mathrm{pH} 11.5\right.$ adjusted with $\mathrm{NaOH}, \mathrm{S}: \mathrm{L}$ ratio of $1: 6.7,35^{\circ} \mathrm{C}, 24 \mathrm{~h}$ ) followed by enzymatic saccharification, a yield for the monomeric sugars of $90 \%$ was reached [18], whereas dilute acid treatment $\left(1 \% \mathrm{H}_{2} \mathrm{SO}_{4}(\mathrm{v} / \mathrm{v})\right.$, S:L ratio of $1: 6.7,121^{\circ} \mathrm{C}, 1 \mathrm{~h}$ ) followed by enzymatic saccharification under the same conditions yielded $60 \%$ monomeric sugars [68].

\subsection{Industrial Applications}

In the frame of second-generation ethanol production, mild alkaline treatment was developed for the fractionation step by some companies, such as SuGanit. The company set a sequential treatment of lignocellulosic biomass with ionic liquid fractionation followed by mild alkaline treatment to generate cellulosic and lignin fractions [69]. This is a two-step process: first lignocellulosic biomasses are contacted with an ionic liquid for about $2 \mathrm{~h}$ to swell the lignocellulosic biomass without dissolution of the lignocellulosic biomass in the ionic liquid; and secondly, the swelled lignocellulosic biomass is treated under mild alkaline conditions with $5 \%(\mathrm{w} / \mathrm{v}) \mathrm{NaOH}$ for about $1 \mathrm{~h}$ at about $75^{\circ} \mathrm{C}$ to separate the lignin from the cellulose and hemicelluloses. The yields of monomeric sugars after enzymatic saccharification reached about $95 \%$ and $65 \%$ for glucose and xylose, respectively.

Mild alkaline fractionation can also be adapted to existing industrial pulp and paper processes. For instance, mild alkaline pre-extraction $\left(10 \% \mathrm{NaOH}(\mathrm{w} / \mathrm{v}), 90^{\circ} \mathrm{C}, 1 \mathrm{~h}\right)$ before soda-anthraquinone pulping (anthraquinone is a catalyst sometimes added to the soda pulping process) largely preserved the pulp yield, while a substantial amount of xylan was pre-extracted under polymeric form (about $15 \mathrm{kDa}$ ), allowing specific valorization where long oligomeric chains are required [70].

\section{Purification Routes Applied to Alkaline Hydrolysates}

Mild alkaline fractionation applied to lignocellulosic biomass coupled with enzymatic saccharification and fermentation of the solid residue containing cellulose is more efficient than acid fractionation for the production of cellulosic ethanol. However, the cost of bases, such as sodium hydroxide, is high, making mild alkaline fractionation uncompetitive for large scale plants [71]. Mild alkaline hydrolysates are composed of lignin oligomers, hemicelluloses oligomers, phenolic monomers, acetic acid, and salts. Some of these compounds present high added value, but their purification is required to make their valorization possible and improve the economic efficiency of biorefineries using a mild alkaline fractionation process [32]. The purification usually focuses on hemicelluloses oligomers or lignin oligomers and consists of removing inorganic salts (sodium hydroxide used in the process and potentially solubilized silica from the biomass), acetate and phenolic monomers. However, purifying and valorizing, inorganic salts (to reuse them in the process), acetate or phenolic monomers can bring additional economic value to the process. Purification can also occur within a given pool of molecules, for instance, lignin oligomers can be further separated depending on their size or their functional groups for various application [22]. Research on the separation of the components of mild alkaline hydrolysates is very recent. Since their composition is similar to those of 
lignocellulosic alkaline hydrolysates obtained in severe conditions, the purification routes described here include both types of alkaline hydrolysates.

\subsection{Flocculation}

Lignin can be flocculated from alkaline hydrolysates obtained with the use of sodium hydroxide, but not from hydrolysates obtained with the use of calcium hydroxide [29]. With the addition of calcium chloride in sodium hydroxide hydrolysate, calcium ions can replace the sodium ions to bridge the negative charges of lignin components and induce the flocculation of lignin. The best lignin recovery ( $23 \%$ of the dry solid content of the hydrolysate) by flocculation was obtained with a loading of calcium hydroxide:hydrolysate of 1:11 (w/v).

\subsection{Precipitation}

\subsubsection{Acidification}

In alkaline extracts, i.e., high $\mathrm{pH}$ solutions, phenol, carboxyl, and hydroxyl groups within the lignin are deprotonated making them negatively charged. Acidification of lignocellulosic alkaline extract leads to the precipitation of lignin. Indeed, the acidic environment tends to neutralize through protonation the anionic charges of lignin [72,73]. The neutralization of the charge, prevent repulsion from the different lignin molecules and allow the interaction between aromatic moieties of the different compounds leading to their precipitation. When the $\mathrm{pH}$ is decreased, high molecular weight lignin molecules precipitate first, smaller molecules precipitate at lower $\mathrm{pHs}[72,74,75]$.

This process has been widely studied in the pulp and paper industry and many patents are reported to specify the conditions of lignin precipitation from black liquor [76-79]. By extension, lignin precipitation via acidification was applied to lignocellulosic mild alkaline extract [80].

Sulfuric acid or carbon dioxide are usually used for acidification of Kraft black liquor [8,15]. Other inorganic acids have also been studied for the precipitation of lignin from lignocellulosic alkaline hydrolysates, such as phosphoric, hydrochloric or nitric acid [80]. Phosphoric acid gave the higher yield of precipitation for the lignin but its price and the larger volume required for the $\mathrm{pH}$ adjustment compare to sulfuric acid, is making sulfuric acid more efficient [80]. The precipitation is usually run at a temperature ranging from 60 to $85^{\circ} \mathrm{C}$, then the precipitate is recovered by filtration (filter press industrially), centrifugation or decantation $[8,76]$. The temperature influences the yield of the precipitate, temperatures higher than $50{ }^{\circ} \mathrm{C}$ are required to reach the highest yields [80]. The temperature also affects the size of lignin flocks, which in turn affects the precipitate/supernatant separation by filtration, good filterability occurring above $70{ }^{\circ} \mathrm{C}$ [81]. However, at temperatures above $85^{\circ} \mathrm{C}$, the acid precipitated lignin become soft and tacky and large clumps of lignin bound together making the mixing difficult [15]. For the acidification, sulfuric acid can be added at high concentration (about 72\% (v/v)) [59] or diluted (about 2\% (v/v) [80,82].

When the black liquor ( $\mathrm{pH}$ 13.8) from oil palm empty fruit bunch was precipitated with phosphoric acid, $\mathrm{pH} 2$ was the optimum for the highest recovery of lignin, further acidification did not improve the recovery [41]. On centrifuged black liquor from wheat straw, an optimal $\mathrm{pH}$ of 3.5 was determined for the acidification of the black liquor based on the yield of precipitation for the lignin $(80 \%)$ and on the consumption of sulfuric acid (100 $\mathrm{mEq} / \mathrm{L}$ of black liquor) [83]. Differential acid precipitation of lignin on alkaline hydrolysate $\left(7.5 \% \mathrm{NaOH}(\mathrm{w} / \mathrm{w}), 90^{\circ} \mathrm{C}, 90 \mathrm{~min}\right)$ from apple tree pruning waste showed that $20 \%$ of the lignin was recovered with acidification until $\mathrm{pH} 6-5$, then about $80 \%$ of the lignin was recovered when the $\mathrm{pH}$ was further adjusted to 2 [59]. When sulfuric acid was added at $80^{\circ} \mathrm{C}$ to softwood black liquor until the $\mathrm{pH}$ was decreased to $9,67-77 \%$ of the lignin was recovered and when $\mathrm{pH}$ was decreased to 3, up to $93-95 \%$ of the lignin was recovered with the sodium content of the precipitate decreasing with decreasing $\mathrm{pH}$ [15]. Another study on softwood black liquor with sequential precipitation at $\mathrm{pH}$ $10.5,5$ and 2.5, showed that majority of the lignin (74-89\%) was precipitated at $\mathrm{pH} 5$, whereas a further decrease in $\mathrm{pH}$ to 2.5 increased the precipitation yield only by $4-5 \%$ [75]. 
Acid precipitated lignin usually showed very high ash contents (up to $55 \%(\mathrm{w} / \mathrm{w})$ of precipitate) [59], which required extensive washing with dilute sulfuric acid and water to eliminate the salts $[8,15]$. Sugars are also recovered in the precipitate, thus decreasing the purity of the lignin. SCB black liquor obtained from the soda-anthraquinone pulping process, precipitated by sulfuric acid until $\mathrm{pH} 3$ at $65^{\circ} \mathrm{C}$, and then, washed with hot water $\left(50^{\circ} \mathrm{C}\right)$ led to a purity of lignin of $70 \%$, with the $30 \%$ remaining being carbohydrates [50]. To increase lignin purity, some studies proposed a two-step precipitation process as carbohydrates, silica and other inorganic salts tend to precipitate together with lignin at $\mathrm{pH}$ about 7 to 5 , then lignin with higher purity was precipitated between $\mathrm{pH} 5$ and $3[80,82]$. However, another study on softwood black liquor, with sequential precipitation at $\mathrm{pH}$ of $10.5,5$ and 2.5 showed opposite results since lignin precipitated at lower $\mathrm{pH}$ had a lower purity due to more co-precipitated sugars [75]. An extensive wash of the lignin did not remove the hemicellulosic sugars probably due to the polymeric form of xylan and its linear structure making it insoluble in water [75].

Metso corporation published several patents about lignin separation from black liquor by acid precipitation, among which, WO 2006/031175 [76] disclosed the basic two-stage acidic process and WO2006/038863 [78] disclosed an improvement of the process where sulfate ions are added to the process. $\mathrm{pH}$ was adjusted to 1-3.5 with carbon dioxide or sulfuric acid, then a press filter was used to separate the lignin precipitate from the black liquor, and the cake was rinsed with the acid solution $(\mathrm{pH}$ from 1 to 3.5) [76]. The addition of sulfate ions (e.g., in the form of sodium sulfate) into the black liquor before precipitation, enabled the increase of lignin yield [78]. For instance, the addition of sodium sulfate to the black liquor with a ratio of $1: 20(\mathrm{w} / \mathrm{v})$, before acidification with carbon dioxide until $\mathrm{pH}$ 9.6 at $80{ }^{\circ} \mathrm{C}$ enabled to increase the lignin yield from 60.5 to $66.8 \%$. Innventia, a Swedish company, is precipitating lignin from softwood Kraft black liquor ( $\mathrm{pH} 13$ ) by the addition of carbon dioxide or mineral acid at $80^{\circ} \mathrm{C}$ until $\mathrm{pH} 8$ only [8].

\subsubsection{Ethanol Addition}

Ethanol addition to lignocellulosic alkaline extract leads to the precipitation of the hemicelluloses, whereas the lignin remains dissolved. Ethanol is the solvent most commonly used, but other organic solvents have also been applied for the precipitation of hemicelluloses [38]. Hemicelluloses, like polysaccharides, contained many hydroxyl groups that form hydrogen bonds with the water molecules. When ethanol is added, it adheres to the polysaccharides through hydrophobic interactions and rearranges hydrogen bonds between water and ethanol, resulting in the possibility for the polysaccharide chains to set hydrogen bonds between each other, thus inducing their precipitation $[84,85]$.

Ethanol concentration in the hydrolysate after ethanol addition is the operating condition having the most influence on the precipitation yield for the hemicelluloses [86]. Increasing the final concentration of ethanol led to higher yields of precipitated hemicelluloses; yields of hemicelluloses ranged from $70-80 \%$ with an ethanol concentration of $70 \%(\mathrm{v} / \mathrm{v})$ or above, and 80 to $95 \%$ with concentration of ethanol at $80 \%(\mathrm{v} / \mathrm{v})$ or above, depending on the initial biomass and on the conditions of extraction of the hemicelluloses [86-89]. The structural features of polysaccharides (e.g., nature of the sugar or ramifications) also impacted the precipitation behavior and the yields. Higher arabinose/xylose ratios were obtained in the precipitated hemicelluloses, with increasing concentration of ethanol $[54,89]$. In hydrolysates with ethanol at $80 \%(\mathrm{v} / \mathrm{v})$, the hemicelluloses still dissolved are short-chained polysaccharides [38]. It was confirmed using a synthetic solution of glucans; as the molecular size of the glucans increased from $1 \mathrm{kDa}$ to $270 \mathrm{kDa}$, the precipitate yield increased from $10 \%$ to $100 \%$ in ethanol $80 \%(\mathrm{v} / \mathrm{v})$ [86]. Finally, addition of ethanol $95 \%(\mathrm{v} / \mathrm{v})$ at room temperature with constant stirring for a few minutes to an hour or initial stirring associated with sedimentation at lower temperatures $\left(4-6^{\circ} \mathrm{C}\right)$ for a few hours to 12 hours are the main process described, then the precipitated hemicelluloses are recovered by centrifugation or by filtration on $0.45 \mu$ m nylon $[38,65,89,90]$.

However, ethanol addition to mild alkaline hydrolysates, leads to the co-precipitation of lignin, impacting the purity of the precipitated hemicelluloses and the recovery of lignin in the supernatant. 
For instance, the precipitation of hemicelluloses from a wheat straw mild alkaline extract by the addition of ethanol, with an ethanol:extract ratio of $4: 1(\mathrm{v} / \mathrm{v})$, led to the recovery of $38 \%$ of the lignin in the precipitated hemicellulosic fraction [37].

Depending on which fraction is the most important at the outlet of the purification step, the process can be adjusted to favor the purity or recovery of lignin or hemicelluloses. Indeed, in some processes, $\mathrm{pH}$ was first adjusted to 5-7, then 3-4 volumes of ethanol were added to precipitate the hemicelluloses, and finally, the ethanol was evaporated and the $\mathrm{pH}$ was lowered down to 1.5-2 to precipitate the lignin $[37,41,91,92]$. This process applied on corncob mild peroxide-alkaline hydrolysate led to $89 \%$ recovery for the hemicelluloses after the first precipitation step and $78 \%$ recovery for the lignin after the second precipitation step [91]. A pH adjustment to 5-7 with acid addition before ethanol addition increased the recovery of precipitated hemicelluloses but led to the co-precipitation of some lignin, and therefore decreased hemicelluloses purity and but increased the purity of the lignin fraction [92].

\subsection{Adsorption}

\subsubsection{Activated Charcoal}

Activated charcoal, also known as activated carbon, is usually used on lignocellulosic alkaline hydrolysates to adsorb high molecular weight lignin, whereas carbohydrates remained mainly unadsorbed, and phenolic monomers present different behaviors [93,94]. The adsorption of lignin onto activated charcoal is an endothermic and spontaneous process, and at least two layers of lignin can be adsorbed [95]. Adsorption of phenol molecules on activated charcoal is controlled by the dispersion force between the $\pi$-electrons in activated charcoal, under the form of carboxyls, lactones, aldehydes, and ketones groups among others, and those in phenolic molecules [96].

In the literature, the treatment of lignocellulosic alkaline extracts by activated charcoal was mainly carried out to pretreat the extracts before further purification by adsorption on anion exchange resins $[25,93,94]$. Adsorption of lignin on activated charcoal before adsorption on resin enabled good recycling of the anionic resin [93]. The targeted molecules were either adsorbed on the activated charcoal like FA [25], or the molecules considered impurities were adsorbed whereas the targeted molecules were not, like $p$-CA [93], and hemicelluloses [94]. For instance, when activated charcoal was added to an SCB alkaline extract, $p$-CA was weakly adsorbed (14\%) and could be separated from lignin and FA that were adsorbed at $80 \%$ [93].

The adsorption of FA from a neutralized SCB alkaline extract was strongly influenced by the ratio of activated charcoal:extract $(\mathrm{w} / \mathrm{v})$; indeed a ratio of 1:100 enabled the adsorption of $48 \% \mathrm{FA}$, whereas a ratio of 3:100 enabled the fixation of $98 \%$ FA [25]. Sequential desorption can help in purifying FA, for instance, water at $90{ }^{\circ} \mathrm{C}$ or acetic ether desorbed $60 \%$ of the color and $10 \%$ of the FA, then sodium hydroxide at $2 \%(\mathrm{w} / \mathrm{v})$ desorbed $85 \%$ of the adsorbed FA and $40 \%$ of the total desorbed color [25].

\subsubsection{Resin}

Adsorption of phenol from a synthetic solution is affected by the $\mathrm{pH}$ of the solution and the resin used [97]. A non-functionalized resin with a polystyrene-divinylbenzene (PS-DVB) matrix, reported maximum loading capacity under acidic conditions, where undissociated phenol form predominates. In contrast, an anion exchange resin, also with a PS-DVD matrix, reported a higher loading capacity under optimized conditions ( $91 \%$ of phenol adsorbed at equilibrium) than a non-functionalized resin (65\% of phenol adsorbed at equilibrium), but under alkaline conditions, where phenoxide form predominated, and thus, a combined effect of both adsorption and ion exchange mechanisms occurred. From the same study, desorption of phenol with sodium hydroxide on the non-functionalized resin was inefficient, but a solution of methanol:water 1:1 (v/v) yielded a 90\% recovery. On the anion exchange resin, desorption with sodium chloride at $4 \%(\mathrm{w} / \mathrm{v})$ at $\mathrm{pH} 12$ yielded a recovery of $90 \%$ for phenol [97].

The adsorption of FA from a mild alkaline maize bran extract was tested on a polyvinyl polypyrrolidone resin, involving hydrogen binding with phenolic and carboxyl groups, and on 
non-functionalized PS-DVB resins, involving hydrophobic interaction with the aromatic ring of FA [27]. The later resins led to a higher binding capacity. After desorption from the non-functionalized PS-DVB resin, Amberlite XAD-16, with an ethanol: $\mathrm{NH}_{3}$ solution at a ratio of 1000:1 (v/v), the purity of FA was $51 \%$ and its recovery was $58 \%$. Purification by adsorption on the resin was also performed on $p$-CA from a mild alkaline sugarcane bagasse extract [26]. $85 \%$ of the $p$-CA was adsorbed on a strong base anion exchange PS-DVB resin packed in a column. Optimization on the composition of the desorption solution showed that the best result was obtained with water:ethanol: $\mathrm{HCl}$ solution with a ratio of $36: 60: 4(\mathrm{v} / \mathrm{v} / \mathrm{v})$, desorption of $99 \%$ of the adsorbed phenolic acids was achieved and the purity of $p$-CA was $90 \%$.

For the purification of hemicelluloses from a wheat bran mild alkaline extract, macroporous-type strong base anion exchange resin with an acrylic DVB matrix exhibited better adsorption capacity for the color (lightness of the purified hemicelluloses, $L^{*}=71$, black is 0 , white is 100) than a macroporous-type strong base anion exchange resin with a PS-DVB matrix $\left(L^{*}=69\right)$ and a macroporous-type non-functionalized resin with an aliphatic-DVB matrix $\left(L^{*}=61\right)$ [92]. Ion exchange resins were also used to purify hemicelluloses by adsorbing organic acids (mainly acetic acid); sulfuric acid was suggested for the desorption of acetic acid [94].

\subsection{Low-Pressure Chromatography}

Some chromatographic processes using ion exchange resins on lignocellulosic alkaline extracts have been reported. A pine soda-anthraquinone hydrolysate was acidified until $\mathrm{pH} 1.2$ to precipitate the lignin, then complete separation of aliphatic carboxylic acids and sodium sulfate from the acidified hydrolysate was achieved using chromatography on strong acid cation (SAC) exchange resin and water as eluent [98]. More recently, chromatography on SAC exchange resins with PS-DVB matrix using water as eluent applied on sugarcane bagasse mild alkaline extract has been reported [30]. Depending on the size of the pores of the resin, different separations were obtained by pulse chromatography. On a gel-type resin (pores of about $3 \mathrm{~nm}$ ), phenolic monomers with a carboxyl group (e.g., FA and $p$-CA) were recovered at $75 \%$ in a fast eluted fraction and phenolic monomers without carboxyl group (e.g., vanillin) were recovered in a fraction eluted later at $75 \%$. On a macroporous-type resin (pores of about $20-50 \mathrm{~nm}$ ), a fraction containing the largest oligomers of lignin (14\% recovery) and hemicelluloses ( $30 \%$ recovery) was obtained free from salts, phenolic monomers, and acetic acid.

\subsection{Cross-Flow Membrane Filtration}

Membrane filtration has been used in the pulp and paper industry to concentrate black liquor (hemicelluloses and lignin) and to remove some of the salts $[99,100]$. Hemicelluloses have a low heating value and can be used for other valuable applications, so membrane filtration was studied to concentrate and purify hemicelluloses from black liquor and by extension from other lignocellulosic alkaline extracts $[70,101-103]$. Lignin has a higher heating value than hemicelluloses, but it can be the starting point of a chemical phenolic platform, therefore their concentration and purification from lignocellulosic strong alkaline extract have also been widely studied [99,104,105].

Ultrafiltration, for instance on ceramic membranes (with MWCO values of $0.8 \mu \mathrm{m}, 0.2 \mu \mathrm{m}$, and $50 \mathrm{~nm}$ ) at $30-60{ }^{\circ} \mathrm{C}$, can be used on black liquors from raw materials with high content in silica (e.g., rice straw) to retain lignin $(75 \%)$ and silicate $(80 \%)$, whereas cooking chemicals are recovered in the permeate [106]. Ultrafiltration has been studied to replace the traditional acid precipitation process to recover Kraft lignin, as it presents the advantage of not altering the $\mathrm{pH}$ or the temperature of the black liquor $[15,105]$. Kraft lignin obtained via ultrafiltration were more contaminated by ash than lignin obtained via acidification [15]. However, lignin obtained from the soda pulping process $\left(7.5 \% \mathrm{NaOH}(\mathrm{w} / \mathrm{w}), 90 \mathrm{~min}, 90^{\circ} \mathrm{C}\right)$ of Miscanthus sinensis and then passed through 5, 10 or $15 \mathrm{kDa}$ membranes were less contaminated by hemicelluloses than acid precipitated lignin [103]. Ultrafiltration has been used at one Scandinavian mill to produce Karatex $\AA$, a Kraft lignin used as an extender for phenol-formaldehyde resin in the manufacture of plywood [15]. Both organic and ceramic membranes 
can retain lignin, but ceramic membranes can be used at higher temperatures, and therefore higher flux can be achieved, but a side effect is the lower retention of lignin. Filtration of black liquors at $145^{\circ} \mathrm{C}$ and $\mathrm{pH}$ of $13-14$ at 4 bar on $15 \mathrm{kDa}$ and $5 \mathrm{kDa}$ ceramic membranes led to fluxes of 100 and $50 \mathrm{~L} / \mathrm{h} / \mathrm{m}^{2}$ but low retention of lignin with $20 \%$ and $30 \%$, respectively [104].

Retention of hemicelluloses from black liquor, whereas lignin was recovered in the permeate, has also been demonstrated by membrane filtration, and the most efficient membranes had usually an MWCO between 1 and $15 \mathrm{kDa}[15,102,104,105,107]$. However, the MWCO of the membranes has to be adapted for every alkaline lignocellulosic extract as the variability of raw materials and extraction conditions lead to different sizes and configuration of hemicelluloses and lignin oligomers. For instance, the concentration of black liquor from hardwood by a volume reduction factor (VRF) of 3 carried out on a $15 \mathrm{kDa}$ ceramic membrane at $1 \mathrm{bar}, 5.0 \mathrm{~m} / \mathrm{s}$ and $90{ }^{\circ} \mathrm{C}$ resulted in an average flux of $33 \mathrm{~L} / \mathrm{h} / \mathrm{m}^{2}$, in the retention of $15-25 \%$ of the lignin and in the retention of $75-95 \%$ of the hemicelluloses, whereas cooking chemicals (sodium hydroxide and sodium sulfide) were not retained [105]. On the contrary, lignin and hemicelluloses were not separated from a mild alkaline extract of sugarcane bagasse by filtration on 1 to $50 \mathrm{kDa}$ organic and inorganic membranes, both compounds being retained over $90 \%$ at $20^{\circ} \mathrm{C}$ on a $10 \mathrm{kDa}$ polysulfone hollow fiber membrane whereas inorganic salts, acetic acid and phenolic monomers passed through the membrane [108]. Membranes with even smaller MWCO, for instance about $200-400 \mathrm{Da}$, can retain more than $97 \%$ of the hemicelluloses from a wood steam hydrolysate, but are not suitable for purifying hemicelluloses extracts as small molecules present high retention rate as well, i.e., acetic acid (70\%), furfural (70\%) or HMF (85\%) [109].

Membrane filtration processes are mainly operated in concentration mode, where the volume reduction factor (VRF) corresponds to the ratio of the initial volume of solution to filter (feed) on the volume of the retentate, and in diafiltration mode, where a given volume of solvent (usually water) is added continuously or discontinuously at the same rate as the removal rate of permeate. Concentration by a VRF of 3.4 of Eucalyptus globulus cold caustic extract on flat-sheet polyethersulfone membrane of $10 \mathrm{kDa}$ at $40{ }^{\circ} \mathrm{C}$ with a cross-flow velocity in the range of 1 to $3 \mathrm{~L} / \mathrm{min}$ and a transmembrane pressure (TMP) in the range of 2 to 8 bar, led to an increase in concentration of xylans up to $67.4 \mathrm{~g} / \mathrm{L}$ from $22.0 \mathrm{~g} / \mathrm{L}$, and at the same time, their concentration in permeate was lower than $1 \mathrm{~g} / \mathrm{L}$ [70]. The concentration of sodium hydroxide was maintained in the retentate around $80 \mathrm{~g} / \mathrm{L}$, so the xylans $/ \mathrm{NaOH}$ ratio was increased from 0.28 to 0.84 . Purification can be improved if the filtration is carried out in diafiltration mode [15], 90\% of the impurities can be removed when 2.3 diavolumes of water are used before concentration by VRF 2 of softwood black liquor on $25 \mathrm{kDa}$ polysulfone membrane at $60^{\circ} \mathrm{C}$. The permeate flux for dialysis and post-concentration was 90 and $70 \mathrm{~L} / \mathrm{h} / \mathrm{m}^{2}$, respectively, with a global lignin recovery of $54 \%$.

Caustic silicate also known as waterglass can be found at high levels in black liquors from raw materials with high content in silica, such as herbaceous biomass, and recovered in the permeate and further valorize for application such as detergents, paper, water treatment, and construction materials [110].

The initial water flux of the membrane, used to check the efficiency of a cleaning procedure after the filtration of an alkaline hydrolysate, should be measured after the rinsing of the new membrane with an alkaline solution (e.g., sodium hydroxide). Indeed, an alkaline solution increases the hydrophilicity and the flux, by the swelling of the membrane $[70,111]$. Cleaning is usually performed at low TMP in order to avoid compression of a possible cake formed at the membrane surface [104]. Care is needed when membranes are cleaned after the treatment of Kraft cooking liquors because the solubility of lignin decreases when the $\mathrm{pH}$ decreases. This means that if the water is used for rinsing, lignin could precipitate and foul the membranes. If the permeate is not of interest, a cleaning method based on the use of collected permeate as the first rinsing solution, followed by synthetic alkaline solution cleaning was successfully tested [104]. 


\subsection{Electrodialysis}

Electrodialysis was studied to acidify black liquor to recover lignin through precipitation and at the same time to recycle sodium hydroxide [100]. Hydrogen ions were produced in the black liquor stream leading to a decrease in $\mathrm{pH}$ and thus the precipitation of the lignin, and they also replaced the sodium ions that migrated into the sodium hydroxide stream. The implementation of electrodialysis led to a lower chemical consumption than the traditional acidification method previously described.

\subsection{Combination of Different Purification Techniques}

The previously detailed purification technologies present different modes of action and limits that are summarized in Table 2. The cost and environmental impact of the purification techniques were not included. The cost analysis is inherently complex and it needs to take into account local factors (e.g., the biomass used or the local cost of utilities). The environmental impact can be directly or indirectly converted as a cost, for instance, using an organic solvent as desorption solvent after adsorbing molecules on activated charcoal or resin is often considered as non-environmental friendly, but this can be converted into the cost of recycling the solvent through distillation to make the process environmentally friendly.

These technologies have sometimes been combined in integrated purification processes of lignocellulosic alkaline extracts to overcome their individual limits and reach a higher level of purification. Examples of integrated processes are presented below.

In the study of Zhao et al. (2011), the purification of $p$-CA from SCB mild alkaline extract involved ultrafiltration, adsorption on activated charcoal, adsorption on anion exchange resin and finally crystallization [93]. Ultrafiltration on a $3 \mathrm{kDa}$ hollow fiber membrane produced a permeate free of hemicelluloses and lignin oligomers, but still containing phenolic monomers responsible for a brown color and considered impurities. The addition of activated charcoal in the permeate with a ratio of $3: 100(\mathrm{w} / \mathrm{v})$, was the optimal ratio to remove the color ( $78 \%$ of removal), whereas $14 \%$ of the $p$-CA was adsorbed. The removal of these phenolic compounds improved the adsorption and desorption performance of anion exchange resins after several adsorption-desorption cycles. $p$-CA was crystallized from the desorption solution (water:ethanol: $\mathrm{HCl}$ at a ratio of $36: 60: 4(\mathrm{v} / \mathrm{v} / \mathrm{v})$ ), by evaporating the ethanol and the resulting crystal had a purity of $95.2 \%$ for $p$-CA. Overall, $8 \mathrm{~g}$ of $p$-CA was formed from $1 \mathrm{~kg}$ of SCB.

Another method was developed by Buranov and Mazza (2009) to purify FA and hemicelluloses from lignocellulosic mild alkaline hydrolysates, using a combination of neutralization, ethanol precipitation, ultrafiltration and a second ethanol precipitation step [65]. After neutralization of the alkaline extract and addition of ethanol $95 \%(\mathrm{v} / \mathrm{v})$ to reach an extract:ethanol ratio of $65: 35(\mathrm{v} / \mathrm{v})$, wax and glucomannans were precipitated. They were separated by centrifugation and the supernatant was ultrafiltrated on a $30 \mathrm{kDa}$ PS membrane resulting in the separation of high polymeric hemicelluloses in the retentate from oligomeric hemicelluloses and FA in the permeate. Oligomeric hemicelluloses were precipitated from the permeate by the addition of ethanol and FA was recovered after evaporation of the ethanol. However, no purity and recovery values for hemicelluloses and FA were reported.

An integrated process to produce purified hemicelluloses from a wheat bran alkaline extract has been developed including ultrafiltration and adsorption steps [90]. The alkaline extract was first separated from the solid residue of the extraction by centrifuge filtration with a $1 \mu \mathrm{m}$ mesh. A $30 \mathrm{kDa}$ polyethersulfone hollow fiber membrane was used in concentration mode with a VRF of 1.8 and led to the removal of $65 \%$ of the initial salts. The retentate containing hemicelluloses was treated on an anion exchange resin to remove color compounds by adsorption on the resin, $8 \%$ of the xylan being lost by adsorption. 
Table 2. Purification technologies used on the lignocellulosic alkaline extract.

\begin{tabular}{|c|c|c|c|}
\hline $\begin{array}{l}\text { Purification } \\
\text { Technologies }\end{array}$ & Conditions & Mode of Action & Limits \\
\hline Flocculation & $\begin{array}{l}\text { Addition of divalent cation } \\
\left(\text { e.g., } \mathrm{Ca}^{2+}, \mathrm{Mg}^{2+}\right) \\
\text { Batch process }\end{array}$ & Flocculation of lignin & $\begin{array}{l}\text { Limited to sodium } \\
\text { hydroxide extracts, } \\
\text { low recovery of lignin }\end{array}$ \\
\hline $\begin{array}{l}\text { Precipitation by } \\
\text { acid addition }\end{array}$ & $\begin{array}{l}\text { Sulfuric acid is mainly used } \\
(2 \% \text { v/v to } 72 \% \mathrm{v} / \mathrm{v}) \\
\text { pH adjusted to } 2-5 \\
\text { Temperature: } 60-85{ }^{\circ} \mathrm{C} \\
\text { Batch process }\end{array}$ & $\begin{array}{l}\text { Precipitation of lignin } \\
(80-95 \%)\end{array}$ & $\begin{array}{l}\text { Lignin purity: } \\
\text { co-precipitation of } \\
\text { sugars, } \\
\text { extensive washing of the } \\
\text { precipitated lignin to } \\
\text { remove the salts }\end{array}$ \\
\hline $\begin{array}{l}\text { Precipitation by } \\
\text { ethanol addition }\end{array}$ & $\begin{array}{c}\text { Final ethanol concentration in } \\
\text { the hydrolysate: } 80-95 \% \mathrm{v} / \mathrm{v} \\
\text { Room temperature } \\
\text { Batch process }\end{array}$ & $\begin{array}{c}\text { Precipitation of } \\
\text { hemicelluloses (80-95\%) }\end{array}$ & $\begin{array}{c}\text { Hemicelluloses purity: } \\
\text { co-precipitation of lignin } \\
\text { High volume of solvent } \\
\text { is required (recycling is } \\
\text { necessary) }\end{array}$ \\
\hline Adsorption on AC & $\begin{array}{c}\text { AC:hydrolysate ratio 3:100 } \\
(\mathrm{w} / \mathrm{v}) \\
\text { Batch process }\end{array}$ & $\begin{array}{l}\text { Adsorption of lignin and } \\
\text { ferulic acid (80-98\%) } \\
\text { Low adsorption of } \\
\text { hemicelluloses and } p \text {-CA }\end{array}$ & $\begin{array}{l}\text { Sodium hydroxide } 2 \% \\
(\mathrm{w} / \mathrm{v}) \text { is required for the } \\
\text { desorption }\end{array}$ \\
\hline $\begin{array}{l}\text { Adsorption on } \\
\text { non-functionalized } \\
\text { resin }\end{array}$ & $\begin{array}{l}\text { pH adjustment (acidification) } \\
\text { Resin packed in a column } \\
\text { Continuous process can } \\
\text { potentially be applied }\end{array}$ & $\begin{array}{l}\text { Adsorption of phenolic } \\
\text { compounds (about 60\%) }\end{array}$ & $\begin{array}{c}\text { Low adsorption capacity } \\
\text { Desorption with organic } \\
\text { solvent }\end{array}$ \\
\hline $\begin{array}{l}\text { Adsorption on } \\
\text { anion-exchange } \\
\text { resin }\end{array}$ & $\begin{array}{l}\text { No pH adjustment } \\
\text { Resin packed in a column } \\
\text { Continuous process can } \\
\text { potentially be applied }\end{array}$ & $\begin{array}{l}\text { Adsorption of phenolic } \\
\text { compounds (70-90\%) } \\
\text { Desorption up to } 99 \% \\
\quad \text { (e.g., for } p \text {-CA) }\end{array}$ & $\begin{array}{l}\text { Desorption with sodium } \\
\text { chloride }(4 \%) \text { or organic } \\
\text { solvent }\end{array}$ \\
\hline $\begin{array}{l}\text { Low-pressure } \\
\text { chromatography }\end{array}$ & $\begin{array}{c}\text { Macroporous cation-exchange } \\
\text { resin } \\
\text { Water as eluent } \\
\text { Continuous process can } \\
\text { potentially be applied }\end{array}$ & $\begin{array}{l}\text { High molecular weight } \\
\text { lignin and } \\
\text { hemicelluloses obtained } \\
\text { in a fast eluted fraction } \\
\text { free of salts, phenolic } \\
\text { monomers, and acetic } \\
\text { acid }\end{array}$ & $\begin{array}{l}\text { Low lignin and } \\
\text { hemicelluloses recovery } \\
(15 \% \text { and } 30 \%, \\
\text { respectively })\end{array}$ \\
\hline $\begin{array}{l}\text { Membrane } \\
\text { filtration }\end{array}$ & $\begin{array}{l}\text { High temperatures (about } 100 \\
{ }^{\circ} \mathrm{C} \text { ) on ceramic membranes } \\
\text { leading to high fluxes } \\
\text { Lower temperatures ( } 20-40 \\
{ }^{\circ} \mathrm{C} \text { ) on organic membranes } \\
\text { UF and NF membranes } \\
\text { (MWCO from } 100 \text { Da to } 30 \\
\text { kDa) } \\
\text { Continuous process can } \\
\text { potentially be applied }\end{array}$ & $\begin{array}{c}\text { Lignin and } \\
\text { hemicelluloses recovered } \\
\text { in the retentate to } \\
\text { different extent (up to } \\
95 \% \text { ) } \\
\text { Phenolic monomers, } \\
\text { acetic acid, salts collected } \\
\text { in the permeate }\end{array}$ & $\begin{array}{l}\text { Usually no separation of } \\
\text { lignin and } \\
\text { hemicelluloses (but it } \\
\text { depends on the biomass } \\
\text { and the alkaline } \\
\text { conditions of the } \\
\text { fractionation) }\end{array}$ \\
\hline Electrodialysis & $\begin{array}{c}\text { Current density: } 330 \mathrm{~A} / \mathrm{m}^{2} \\
\text { Temperature: } 35{ }^{\circ} \mathrm{C} \\
\text { Batch process so far }\end{array}$ & $\begin{array}{l}\text { Precipitation of lignin via } \\
\text { acidification and } \\
\text { recovery of sodium ions }\end{array}$ & Studies are missing \\
\hline
\end{tabular}

\section{Conclusions}

Among the variety of fractionation processes that can be applied to lignocellulosic biomass, mild alkaline fractionation presents interesting advantages. Both hemicelluloses and lignin are solubilized under the oligomeric form, which opens up different valorization pathways, than monomeric sugars obtained in the acid fractionation process for example. The rate of solubilization depends on the severity of the conditions employed and on the lignocellulosic biomass treated, but 60 to $80 \%$ solubilization for lignin and hemicelluloses can reasonably be achieved with mild alkaline conditions. 
Besides, better enzymatic saccharification of cellulose, contained in the solid residue, was achieved compared to the traditional acid fractionation process.

Lignocellulosic mild alkaline extracts contain pools of molecules similar to those obtained under severe alkaline conditions (black liquors), made of oligomeric hemicelluloses, oligomeric lignin, phenolic monomers, acetic acid, and inorganic salts. So far, purification strategies mainly rely on precipitation of lignin by the addition of acid, adsorption of phenolic molecules by AC or resins and membrane filtration to separate oligomers of lignin and hemicelluloses from inorganic salts, acetic acid and phenolic monomers. Low-pressure chromatography with the use of polymeric resins as sorbents and water as eluent is an environmentally friendly technique that recently showed interesting results that could be further explored for the purification of lignocellulosic mild alkaline extracts. New purification technologies could emerge but future works might focus on associating the technologies presented in this paper to produce purified pools of molecules ready for further transformation and valorization.

Author Contributions: Conceptualization: V.O. and P.-Y.P.; writing, original draft preparation: V.O.; review and editing: V.O., J.P., and P.-Y.P. All authors have read and agreed to the published version of the manuscript.

Funding: The authors are grateful to the ANR (Agence National de la Recherche) for the financial support of this research in the frame of the LigNov project (ANR-14-CE06-0025-01).

Conflicts of Interest: The authors declare no conflict of interest.

\section{References}

1. Balan, V. Current challenges in commercially producing biofuels from lignocellulosic biomass. ISRN Biotechnol. 2014, 2014, 463074. [CrossRef]

2. Ragauskas, A.J.; Beckham, G.T.; Biddy, M.J.; Chandra, R.; Chen, F.; Davis, M.F.; Davison, B.H.; Dixon, R.A.; Gilna, P.; Keller, M.; et al. Lignin valorization: Improving lignin processing in the biorefinery. Science 2014, 344, 1246843. [CrossRef]

3. Alvira, P.; Tomás-Pejó, E.; Ballesteros, M.; Negro, M.J. Pretreatment technologies for an efficient bioethanol production process based on enzymatic hydrolysis: A review. Bioresour. Technol. 2010, 101, 4851-4861. [CrossRef] [PubMed]

4. Cardona, C.A.; Quintero, J.A.; Paz, I.C. Production of bioethanol from sugarcane bagasse: Status and perspectives. Bioresour. Technol. 2010, 101, 4754-4766. [CrossRef] [PubMed]

5. Oriez, V.; Peydecastaing, J.; Pontalier, P.-Y. Lignocellulosic biomass fractionation by mineral acids and resulting extract purification processes: Conditions, yields, and purities. Molecules 2019, 24, 4273. [CrossRef] [PubMed]

6. Dixon, J.W. Improved Process for Making Paper-Pulp [Internet]. U.S. Patent 51572A, 28 September 1948. Available online: https://patents.google.com/patent/US51572A/en (accessed on 18 September 2018).

7. Dahl, G.F. Process of Manufacturing Cellulose from Wood [Internet]. U.S. Patent 296935A, 15 April 1884. Available online: https:/patents.google.com/patent/US296935A/en (accessed on 18 September 2018).

8. Eckert, R.C.; Abdullah, Z. Carbon Fibers from Kraft Softwood Lignin [Internet]. U.S. Patent 20080318043 A1, 25 December 2008. Available online: http://www.google.fr/patents/US20080318043 (accessed on 4 September 2015).

9. Cardoso, M.; de Oliveira, É.D.; Passos, M.L. Chemical composition and physical properties of black liquors and their effects on liquor recovery operation in Brazilian pulp mills. Fuel 2009, 88, 756-763. [CrossRef]

10. Christensen, T. A Mathematical Model of the Kraft Pulping Process. Bachelor's Thesis, The Purdue University, West Lafayette, IN, USA, 1982; pp. 1-535.

11. Phillips, M. Benjamin Chew Tilghman, and the origin of the sulfite process for delignification of wood. J. Chem. Educ. 1943, 20, 444. [CrossRef]

12. Pokhrel, D.; Viraraghavan, T. Treatment of pulp and paper mill wastewater-A review. Sci. Total Environ. 2004, 333, 37-58. [CrossRef]

13. Biermann, C.J. Essentials of Pulping and Papermaking; Academic Press: San Diego, CA, USA, 1993; p. 472. 
14. Niemelä, K.; Sjöström, E. Simultaneous identification of aromatic and aliphatic low molecular weight compounds from alkaline pulping liquor by capillary gas-liquid chromatography-Mass spectrometry. Holzforsch. Int. J. Biol. Chem. Phys. Technol. Wood 1986, 40, 361-368. [CrossRef]

15. Uloth, V.C.; Wearing, J.T. Kraft lignin recovery: Acid precipitation versus ultrafiltration. I. Laboratory Test Results. Pulp Pap Can [Internet]. 1989. Available online: http://agris.fao.org/agris-search/search.do? recordID=US201302658976 (accessed on 23 February 2016).

16. Hayes, D.J. An examination of biorefining processes, catalysts and challenges. Catal. Today 2009, 145, $138-151$. [CrossRef]

17. Kim, J.S.; Lee, Y.Y.; Kim, T.H. A review on alkaline pretreatment technology for bioconversion of lignocellulosic biomass. Bioresour. Technol. 2016, 199, 42-48. [CrossRef] [PubMed]

18. Saha, B.C.; Cotta, M.A. Enzymatic saccharification and fermentation of alkaline peroxide pretreated rice hulls to ethanol. Enzyme Microb. Technol. 2007, 41, 528-532. [CrossRef]

19. Werpy, T.; Petersen, G.; Aden, A.; Bozell, J.; Holladay, J.; White, J.; Elliot, D.; Lasure, L.; Jones, S.; Gerber, M.; et al. Top Value Added Chemicals From Biomass: Volume I-Results of Screening for Potential Candidates from Sugars and Synthesis Gas; U.S. Department of Energy: Oak Ridge, TN, USA, 2004.

20. Ruiz, H.A.; Cerqueira, M.A.; Silva, H.D.; Rodríguez-Jasso, R.M.; Vicente, A.A.; Teixeira, J.A. Biorefinery valorization of autohydrolysis wheat straw hemicellulose to be applied in a polymer-blend film. Carbohydr. Polym. 2013, 92, 2154-2162. [CrossRef] [PubMed]

21. Hu, L.; Du, M.; Zhang, J. Hemicellulose-based hydrogels present status and application prospects: A brief review. Open J. For. 2017, 8, 15. [CrossRef]

22. Holladay, J.; Bozell, J.; White, J.; Johnson, D. Top Value Added Chemicals from Biomass: Volume II-Results of Screening for Potential Candidates from Biorefinery Lignin; U.S. Department of Energy: Oak Ridge, TN, USA, 2007.

23. Norgren, M.; Edlund, H. Lignin: Recent advances and emerging applications. Curr. Opin. Colloid Interface Sci. 2014, 19, 409-416. [CrossRef]

24. El Mansouri, N.-E.E.; Salvadó, J. Structural characterization of technical lignins for the production of adhesives: Application to lignosulfonate, kraft, soda-anthraquinone, organosolv and ethanol process lignins. Ind. Crops Prod. 2006, 24, 8-16. [CrossRef]

25. Ou, S.; Luo, Y.; Xue, F.; Huang, C.; Zhang, N.; Liu, Z. Seperation and purification of ferulic acid in alkaline-hydrolysate from sugarcane bagasse by activated charcoal adsorption/anion macroporous resin exchange chromatography. J. Food Eng. 2007, 78, 1298-1304. [CrossRef]

26. Ou, S.Y.; Luo, Y.L.; Huang, C.H.; Jackson, M. Production of coumaric acid from sugarcane bagasse. Innov. Food Sci. Emerg. Technol. 2009, 10, 253-259. [CrossRef]

27. Tilay, A.; Bule, M.; Kishenkumar, J.; Annapure, U. Preparation of ferulic acid from agricultural wastes: Its improved extraction and purification. J. Agric. Food Chem. 2008, 56, 7644-7648. [CrossRef]

28. Torre, P.; Aliakbarian, B.; Rivas, B.; Domínguez, J.M.; Converti, A. Release of ferulic acid from corn cobs by alkaline hydrolysis. Biochem. Eng. J. 2008, 40, 500-506. [CrossRef]

29. Chang, M.; Li, D.; Wang, W.; Chen, D.; Zhang, Y.; Hu, H.; Ye, X. Comparison of sodium hydroxide and calcium hydroxide pretreatments on the enzymatic hydrolysis and lignin recovery of sugarcane bagasse. Bioresour. Technol. 2017, 244, 1055-1058. [CrossRef] [PubMed]

30. Oriez, V.; Beyerle, M.; Pontalier, P.-Y.; Peydecastaing, J. Sugarcane bagasse mild alkaline fractionation and production of purified fractions by pulse chromatography with water. Ind. Crops Prod. 2018, 125, 370-378. [CrossRef]

31. Mosier, N.; Wyman, C.; Dale, B.; Elander, R.; Lee, Y.Y.; Holtzapple, M.; Ladisch, M. Features of promising technologies for pretreatment of lignocellulosic biomass. Bioresour. Technol. 2005, 96, 673-686. [CrossRef] [PubMed]

32. Wu, L.; Arakane, M.; Ike, M.; Wada, M.; Takai, T.; Gau, M.; Tokuyasu, K. Low temperature alkali pretreatment for improving enzymatic digestibility of sweet sorghum bagasse for ethanol production. Bioresour. Technol. 2011, 102, 4793-4799. [CrossRef]

33. Kim, S.; Holtzapple, M.T. Delignification kinetics of corn stover in lime pretreatment. Bioresour. Technol. 2006, 97, 778-785. [CrossRef]

34. Sun, R.; Lawther, J.M.; Banks, W.B. Influence of alkaline pre-treatments on the cell wall components of wheat straw. Ind. Crops Prod. 1995, 4, 127-145. [CrossRef] 
35. Bunzel, M.; Ralph, J.; Kim, H.; Lu, F.; Ralph, S.A.; Marita, J.M.; Hatfield, R.D.; Steinhart, H. Sinapate dehydrodimers and sinapate-ferulate heterodimers in cereal dietary fiber. J. Agric. Food Chem. 2003, 51, 1427-1434. [CrossRef]

36. Harmsen, P.F.H.; Huijen, W.J.J.; Bermúdez López, L.M.; Bakker, R.R.C. Literature Review of Physical and Chemical Pretreatment Processes for Lignocellulosic Biomass; Report No.: ECN-E-10-013; Wageningen University, Energy Research Centre of The Netherlands: Petten, The Netherlands, 2010.

37. Sun, R.; Fang, J.; Rowlands, P. Physico-chemical and thermal characterization of alkali-soluble lignins from wheat straw. Polym. J. 1998, 30, 289-294. [CrossRef]

38. Sun, R.C.; Tomkinson, J. Essential Guides for Isolation/Purification of Polysaccharides. Encycl. Sep. Sci. 2000, $6,4568-4574$.

39. Sun, J.X.; Sun, X.F.; Sun, R.C.; Su, Y.Q. Fractional extraction and structural characterization of sugarcane bagasse hemicelluloses. Carbohydr. Polym. 2004, 56, 195-204. [CrossRef]

40. Lora, J.H.; Glasser, W.G. Recent industrial applications of lignin: A sustainable alternative to nonrenewable materials. J. Polym. Environ. 2002, 10, 39-48. [CrossRef]

41. Sun, R.; Tomkinson, J.; Bolton, J. Effects of precipitation $\mathrm{pH}$ on the physico-chemical properties of the lignins isolated from the black liquor of oil palm empty fruit bunch fibre pulping. Polym. Degrad. Stab. 1999, 63, 195-200. [CrossRef]

42. Sun, R.; Sun, X.F.; Wang, S.Q.; Zhu, W.; Wang, X.Y. Ester and ether linkages between hydroxycinnamic acids and lignins from wheat, rice, rye, and barley straws, maize stems, and fast-growing poplar wood. Ind. Crops Prod. 2002, 15, 179-188. [CrossRef]

43. Xu, F.; Sun, R.-C.; Sun, J.-X.; Liu, C.-F.; He, B.-H.; Fan, J.-S. Determination of cell wall ferulic and p-coumaric acids in sugarcane bagasse. Anal. Chim. Acta 2005, 552, 207-217. [CrossRef]

44. Hu, L.; Pan, H.; Zhou, Y.; Zhang, M. Methods to improve lignin's reactivity as a phenol subsitute and as replacement for other phenolic compounds: A brief review. BioResources 2011, 6, 3515-3525.

45. Chaturvedi, V.; Verma, P. An overview of key pretreatment processes employed for bioconversion of lignocellulosic biomass into biofuels and value added products. 3 Biotech 2013, 3, 415-431. [CrossRef]

46. Peng, F.; Peng, P.; Xu, F.; Sun, R.-C. Fractional purification and bioconversion of hemicelluloses. Biotechnol. Adv. 2012, 30, 879-903. [CrossRef]

47. Chang, V.S.; Nagwani, M.; Holtzapple, M.T. Lime pretreatment of crop residues bagasse and wheat straw. Appl. Biochem. Biotechnol. 1998, 74, 135-159. [CrossRef]

48. Grimaldi, M.P.; Marques, M.P.; Laluce, C.; Cilli, E.M.; Sponchiado, S.R.P. Evaluation of Lime and Hydrothermal Pretreatments for Efficient Enzymatic hydrolysis of Raw Sugarcane Bagasse. Biotechnol Biofuels [Internet]. 2015. Available online: http://www.ncbi.nlm.nih.gov/pmc/articles/PMC4667421/ (accessed on 18 May 2016).

49. Kim, T.H.; Taylor, F.; Hicks, K.B. Bioethanol production from barley hull using SAA (soaking in aqueous ammonia) pretreatment. Bioresour. Technol. 2008, 99, 5694-5702. [CrossRef]

50. Da Silva, C.G.; Grelier, S.; Pichavant, F.; Frollini, E.; Castellan, A. Adding value to lignins isolated from sugarcane bagasse and Miscanthus. Ind. Crops Prod. 2013, 42, 87-95. [CrossRef]

51. Saha, B.C.; Cotta, M.A. Lime pretreatment, enzymatic saccharification and fermentation of rice hulls to ethanol. Biomass Bioenergy 2008, 32, 971-977. [CrossRef]

52. Vancov, T.; McIntosh, S. Alkali pretreatment of cereal crop residues for second-generation biofuels. Energy Fuels 2011, 25, 2754-2763. [CrossRef]

53. Peng, F.; Ren, J.-L.; Xu, F.; Bian, J.; Peng, P.; Sun, R.-C. Comparative study of hemicelluloses obtained by graded ethanol precipitation from sugarcane bagasse. J. Agric. Food Chem. 2009, 57, 6305-6317. [CrossRef] [PubMed]

54. Sun, J.-X.; Sun, X.-F.; Sun, R.-C.; Fowler, P.; Baird, M.S. Inhomogeneities in the chemical structure of sugarcane bagasse lignin. J. Agric. Food Chem. 2003, 51, 6719-6725. [CrossRef] [PubMed]

55. Yao, S.; Nie, S.; Yuan, Y.; Wang, S.; Qin, C. Efficient extraction of bagasse hemicelluloses and characterization of solid remainder. Bioresour. Technol. 2015, 185, 21-27. [CrossRef] [PubMed]

56. Kim, M.; Aita, G.; Day, D.F. Compositional changes in sugarcane bagasse on low temperature, long-term diluted ammonia treatment. Appl. Biochem. Biotechnol. 2010, 161, 34-40. [CrossRef] [PubMed]

57. Chandel, A.K.; Antunes, F.A.; Silva, M.B.; da Silva, S.S. Unraveling the structure of sugarcane bagasse after soaking in concentrated aqueous ammonia (SCAA) and ethanol production by Scheffersomyces (Pichia) stipitis. Biotechnol. Biofuels 2013, 6, 102. [CrossRef] 
58. Xiao, B.; Sun, X.F.; Sun, R. Chemical, structural, and thermal characterizations of alkali-soluble lignins and hemicelluloses, and cellulose from maize stems, rye straw, and rice straw. Polym. Degrad. Stab. 2001, 74, 307-319. [CrossRef]

59. García, A.; González Alriols, M.; Spigno, G.; Labidi, J. Lignin as natural radical scavenger. Effect of the obtaining and purification processes on the antioxidant behaviour of lignin. Biochem. Eng. J. 2012, 67, 173-185. [CrossRef]

60. Kim, I.; Han, J.-I. Optimization of alkaline pretreatment conditions for enhancing glucose yield of rice straw by response surface methodology. Biomass Bioenergy 2012, 46, 210-217. [CrossRef]

61. Rawat, R.; Kumbhar, B.K.; Tewari, L. Optimization of alkali pretreatment for bioconversion of poplar (Populus deltoides) biomass into fermentable sugars using response surface methodology. Ind. Crops Prod. 2013, 44, 220-226. [CrossRef]

62. Cotana, F.; Barbanera, M.; Foschini, D.; Lascaro, E.; Buratti, C. Preliminary Optimization of Alkaline Pretreatment for Ethanol Production from Vineyard Pruning. Energy Procedia 2015, 82, 389-394. [CrossRef]

63. Łukajtis, R.; Rybarczyk, P.; Kucharska, K.; Konopacka-Łyskawa, D.; Słupek, E.; Wychodnik, K.; Kamiński, M. Optimization of saccharification conditions of lignocellulosic biomass under alkaline pre-treatment and enzymatic hydrolysis. Energies 2018, 11, 886. [CrossRef]

64. Sun, R.-C.; Sun, X.-F.; Zhang, S.-H. Quantitative determination of hydroxycinnamic acids in wheat, rice, rye, and barley straws, maize stems, oil palm frond fiber, and fast-growing poplar wood. J. Agric. Food Chem. 2001, 49, 5122-5129. [CrossRef] [PubMed]

65. Buranov, A.U.; Mazza, G. Extraction and purification of ferulic acid from flax shives, wheat and corn bran by alkaline hydrolysis and pressurised solvents. Food Chem. 2009, 115, 1542-1548. [CrossRef]

66. Brienzo, M.; Siqueira, A.F.; Milagres, A.M.F. Search for optimum conditions of sugarcane bagasse hemicellulose extraction. Biochem. Eng. J. 2009, 46, 199-204. [CrossRef]

67. Hernández-Salas, J.M.; Villa-Ramírez, M.S.; Veloz-Rendón, J.S.; Rivera-Hernández, K.N.; González-César, R.A.; Plascencia-Espinosa, M.A.; Trejo-Estrada, S.R. Comparative hydrolysis and fermentation of sugarcane and agave bagasse. Bioresour. Technol. 2009, 100, 1238-1245. [CrossRef]

68. Saha, B.C.; Iten, L.B.; Cotta, M.A.; Wu, Y.V. Dilute acid pretreatment, enzymatic saccharification, and fermentation of rice hulls to ethanol. Biotechnol. Prog. 2005, 21, 816-822. [CrossRef]

69. Paripati, P.; Dadi, A.P. Pretreatment and Fractionation of Lignocellulosic Biomass [Internet]. U.S. Patent 20140273104 A1, 18 September 2014. Available online: http://www.google.com/patents/US20140273104 (accessed on 3 December 2015).

70. Sixta, H.; Schild, G. A new generation Kraft process. Lenzing. Ber. 2009, 87, 26-37.

71. Sánchez, Ó.J.; Cardona, C.A. Trends in biotechnological production of fuel ethanol from different feedstocks. Bioresour. Technol. 2008, 99, 5270-5295. [CrossRef]

72. Sarkanen, S.; Teller, D.C.; Stevens, C.R.; McCarthy, J.L. Associative interactions between Kraft lignin components. Macromolecules 1984, 17, 2588-2597. [CrossRef]

73. Shi, H.; Fatehi, P.; Xiao, H.; Ni, Y. A combined acidification/PEO flocculation process to improve the lignin removal from the pre-hydrolysis liquor of kraft-based dissolving pulp production process. Bioresour. Technol. 2011, 102, 5177-5182. [CrossRef] [PubMed]

74. Wang, G.; Chen, H. Fractionation of alkali-extracted lignin from steam-exploded stalk by gradient acid precipitation. Sep. Purif. Technol. 2013, 105, 98-105. [CrossRef]

75. Alekhina, M.; Ershova, O.; Ebert, A.; Heikkinen, S.; Sixta, H. Softwood kraft lignin for value-added applications: Fractionation and structural characterization. Ind. Crops Prod. 2015, 66, 220-228. [CrossRef]

76. Axegård, P.; Öhman, F.; Theliander, H.; Tomani, P. Method for Separating Lignin from Black Liquor [Internet]. WO 2006031175 A1, 23 March 2006. Available online: http://www.google.fr/patents/WO2006031175A1 (accessed on 4 September 2015).

77. Littorin, A.; Wallmo, H.; Norberg, H.; Wimby, M. Method for Precipitating Lignin from Black Liquor by Utilizing Waste Gases [Internet]. WO 2010143997 A1, 16 December 2010. Available online: http: //www.google.com/patents/WO2010143997A1 (accessed on 4 September 2015).

78. Öhman, F.; Theliander, H.; Norgren, M.; Tomani, P.; Axegård, P. Method for Separating Lignin from A Lignin Containing Liquid/Slurry [Internet]. WO 2006038863 A1, 13 April 2006. Available online: http://www.google.fr/patents/WO2006038863A1 (accessed on 4 September 2015). 
79. Wallmo, H.; Wimby, M. Method for lignin Separation from Black Liquor Having Removal of Sulphur Compounds from Formed Water Effluent [Internet]. U.S. Patent 20140357847 A1, 4 December 2014. Available online: http://www.google.fr/patents/US20140357847 (accessed on 4 September 2015).

80. Minu, K.; Jiby, K.K.; Kishore, V.V.N. Isolation and purification of lignin and silica from the black liquor generated during the production of bioethanol from rice straw. Biomass Bioenergy 2012, 39, 210-217. [CrossRef]

81. Glasser, W.G.; Wright, R.S. Steam-assisted biomass fractionation. II. fractionation behavior of various biomass resources. Biomass Bioenergy 1998, 14, 219-235. [CrossRef]

82. Mousavioun, P.; Doherty, W.O.S. Chemical and thermal properties of fractionated bagasse soda lignin. Ind. Crops Prod. 2010, 31, 52-58. [CrossRef]

83. Gilarranz, M.A.; Rodriguez, F.; Oliet, M.; Revenga, J.A. Acid precipitation and purification of wheat straw lignin. Sep. Sci. Technol. 1998, 33, 1359-1377. [CrossRef]

84. Umemura, M.; Yuguchi, Y. Solvation of xyloglucan in water/alcohol systems by molecular dynamics simulation. Cellulose 2009, 16, 361-371. [CrossRef]

85. Sedlmeyer, F.B. Xylan as by-product of biorefineries: Characteristics and potential use for food applications. Food Hydrocoll. 2011, 25, 1891-1898. [CrossRef]

86. Xu, J.; Yue, R.-Q.; Liu, J.; Ho, H.-M.; Yi, T.; Chen, H.-B.; Han, Q.B. Structural diversity requires individual optimization of ethanol concentration in polysaccharide precipitation. Int. J. Biol. Macromol. 2014, 67, 205-209. [CrossRef]

87. Brillouet, J.-M.; Joseleau, J.-P.; Utille, J.-P.; Lelièvre, D. Isolation, purification and characterization of a complex heteroxylan from industrial wheat bran. J. Agric. Food Chem. 1982, 30, 488-495. [CrossRef] [PubMed]

88. Bian, J.; Peng, F.; Peng, P.; Xu, F.; Sun, R.-C. Isolation and fractionation of hemicelluloses by graded ethanol precipitation from Caragana korshinskii. Carbohydr. Res. 2010, 345, 802-809. [CrossRef] [PubMed]

89. Peng, P.; Peng, F.; Bian, J.; Xu, F.; Sun, R. Studies on the starch and hemicelluloses fractionated by graded ethanol precipitation from bamboo Phyllostachys bambusoides f. shouzhu Yi. J. Agric. Food Chem. 2011, 59, 2680-2688. [CrossRef] [PubMed]

90. Zeitoun, R.; Pontalier, P.Y.; Marechal, P.; Rigal, L. Twin-screw extrusion for hemicellulose recovery: Influence on extract purity and purification performance. Bioresour. Technol. 2010, 101,9348-9354. [CrossRef] [PubMed]

91. Su, Y.; Du, R.; Guo, H.; Cao, M.; Wu, Q.; Su, R.; Qi, W.; He, Z. Fractional pretreatment of lignocellulose by alkaline hydrogen peroxide: Characterization of its major components. Food Bioprod. Process. 2015, 94 , 322-330. [CrossRef]

92. Sun, R.; Tomkinson, J. Fractional separation and physico-chemical analysis of lignins from the black liquor of oil palm trunk fibre pulping. Sep. Purif. Technol. 2001, 24, 529-539. [CrossRef]

93. Zhao, J.; Ou, S.; Ding, S.; Wang, Y.; Wang, Y. Effect of activated charcoal treatment of alkaline hydrolysates from sugarcane bagasse on purification of p-coumaric acid. Chem. Eng. Res. Des. 2011, 89, 2176-2181. [CrossRef]

94. Shen, J.; Kaur, I.; Baktash, M.M.; He, Z.; Ni, Y. A combined process of activated carbon adsorption, ion exchange resin treatment and membrane concentration for recovery of dissolved organics in pre-hydrolysis liquor of the kraft-based dissolving pulp production process. Bioresour. Technol. 2013, 127, 59-65. [CrossRef]

95. Andersson, K.I.; Eriksson, M.; Norgren, M. Removal of lignin from wastewater generated by mechanical pulping using activated charcoal and fly ash: Adsorption isotherms and thermodynamics. Ind. Eng. Chem. Res. 2011, 50, 7722-7732. [CrossRef]

96. Jung, M.-W.; Ahn, K.-H.; Lee, Y.; Kim, K.-P.; Rhee, J.-S.; Tae Park, J.; Paeng, K.J. Adsorption characteristics of phenol and chlorophenols on granular activated carbons (GAC). Microchem. J. 2001, 70, 123-131. [CrossRef]

97. Caetano, M.; Valderrama, C.; Farran, A.; Cortina, J.L. Phenol removal from aqueous solution by adsorption and ion exchange mechanisms onto polymeric resins. J. Colloid Interface Sci. 2009, 338, 402-409. [CrossRef] [PubMed]

98. Alén, R.; Sjöström, E.; Suominen, S. Application of ion-exclusion chromatography to alkaline pulping liquors; separation of hydroxy carboxylic acids from inorganic solids. J. Chem. Technol. Biotechnol. 1991, 51, 225-233. [CrossRef]

99. Abels, C.; Carstensen, F.; Wessling, M. Membrane processes in biorefinery applications. J. Membr. Sci. 2013, 444, 285-317. [CrossRef]

100. Haddad, M.; Bazinet, L.; Savadogo, O.; Paris, J. A feasibility study of a novel electro-membrane based process to acidify Kraft black liquor and extract lignin. Process Saf. Environ. Prot. 2017, 106, 68-75. [CrossRef] 
101. Huang, H.-J.; Ramaswamy, S.; Tschirner, U.W.; Ramarao, B.V. A review of separation technologies in current and future biorefineries. Sep. Purif. Technol. 2008, 62, 1-21. [CrossRef]

102. Persson, T.; Jönsson, A.-S. Isolation of hemicelluloses by ultrafiltration of thermomechanical pulp mill process water-Influence of operating conditions. Chem. Eng. Res. Des. 2010, 88, 1548-1554. [CrossRef]

103. Toledano, A.; Serrano, L.; Garcia, A.; Mondragon, I.; Labidi, J. Comparative study of lignin fractionation by ultrafiltration and selective precipitation. Chem. Eng. J. 2010, 157, 93-99. [CrossRef]

104. Wallberg, O.; Jönsson, A.-S. Separation of lignin in kraft cooking liquor from a continuous digester by ultrafiltration at temperatures above $100^{\circ} \mathrm{C}$. Desalination 2006, 195, 187-200. [CrossRef]

105. Jönsson, A.-S.; Wallberg, O. Cost estimates of kraft lignin recovery by ultrafiltration. Desalination 2009, 237, 254-267. [CrossRef]

106. Liu, G.; Liu, Y.; Shi, H.; Qian, Y. Application of inorganic membranes in the alkali recovery process. Desalination 2004, 169, 193-205. [CrossRef]

107. Singh, S.C.; Murthy, Z.V.P. Hemicelluloses separation from caustic-containing process stream by ultrafiltration. Sep. Sci. Technol. 2017, 52, 2252-2261. [CrossRef]

108. Oriez, V.; Peydecastaing, J.; Pontalier, P.-Y. Separation of sugarcane bagasse mild alkaline extract components by ultrafiltration-Membrane screening and effect of filtration parameters. Process Biochem. 2019, 78, 91-99. [CrossRef]

109. Ajao, O.; Rahni, M.; Marinova, M.; Chadjaa, H.; Savadogo, O. Retention and flux characteristics of nanofiltration membranes during hemicellulose prehydrolysate concentration. Chem. Eng. J. 2015, 260, 605-615. [CrossRef]

110. Lucas, J.L.; Martin, F.E. Process for Production of Lignin Fuel, Ethyl Alcohol, Cellulose, Silica/Silicates, and Cellulose Derivatives from Plant Biomass [Internet]. U.S. Patent 5735916A, 7 April 1998. Available online: http://www.google.com/patents/US5735916 (accessed on 20 May 2016).

111. Nilsson, M.; Trägårdh, G.; Östergren, K. Influence of temperature and cleaning on aromatic and semi-aromatic polyamide thin-film composite NF and RO membranes. Sep. Purif. Technol. 2008, 62, 717-726. [CrossRef]

(C) 2020 by the authors. Licensee MDPI, Basel, Switzerland. This article is an open access article distributed under the terms and conditions of the Creative Commons Attribution (CC BY) license (http://creativecommons.org/licenses/by/4.0/). 